\title{
Yeast for virus research
}

\author{
Richard Yuqi Zhao* \\ Department of Pathology, Department of Microbiology and Immunology, Institute of Global Health, and Institute of Human Virology, \\ University of Maryland School of Medicine, Baltimore, MD 21201, USA. \\ * Corresponding Author: \\ Richard Y. Zhao, Department of Pathology, Department of Microbiology and Immunology, Institute of Global Health, and Institute of \\ Human Virology, University of Maryland School of Medicine, Baltimore, MD 21201, USA; Tel: +1 410706 6301; \\ E-mail: rzhao@som.umaryland.edu
}

ABSTRACT Budding yeast (Saccharomyces cerevisiae) and fission yeast (Schizosaccharomyces pombe) are two popular model organisms for virus research. They are natural hosts for viruses as they carry their own indigenous viruses. Both yeasts have been used for studies of plant, animal and human viruses. Many positive sense (+) RNA viruses and some DNA viruses replicate with various levels in yeasts, thus allowing study of those viral activities during viral life cycle. Yeasts are single cell eukaryotic organisms. Hence, many of the fundamental cellular functions such as cell cycle regulation or programed cell death are highly conserved from yeasts to higher eukaryotes. Therefore, they are particularly suited to study the impact of those viral activities on related cellular activities during virus-host interactions. Yeasts present many unique advantages in virus research over high eukaryotes. Yeast cells are easy to maintain in the laboratory with relative short doubling time. They are nonbiohazardous, genetically amendable with small genomes that permit genome-wide analysis of virologic and cellular functions. In this review, similarities and differences of these two yeasts are described. Studies of virologic activities such as viral translation, viral replication and genome-wide study of virus-cell interactions in yeasts are highlighted. Impacts of viral proteins on basic cellular functions such as cell cycle regulation and programed cell death are discussed. Potential applications of using yeasts as hosts to carry out functional analysis of small viral genome and to develop high throughput drug screening platform for the discovery of antiviral drugs are presented. doi: 10.15698/mic2017.10.592

Received originally: 02.05.2017;

in revised form: 18.08.2017,

Accepted 27.08.2017,

Published 18.09.2017.

Keywords: Saccharomyces cerevisiae, Schizosaccharomyces pombe, virushost interaction, viral replication, cell cycle regulation, programed cell death, genome-wide analysis, high throughput drug screening.

\section{Abbreviations:}

ACMV - African cassava mosaic virus, CMV-cytomegalovirus,

dsRNA - double stranded RNA,

HCV - Hepatitis C virus,

HIV-1 - human immunodeficiency virus type 1,

HTS - high throughput screening, pRbR protein - plant retinoblastomarelated protein,

$P R$ - protease,

Rep - replication protein,

$R d R P-R N A$-dependent RNA

polymerase,

ssRNA - single stranded RNA,

$T S B V$ - tomato bushy stunt virus,

$V p r-v i r a l$ protein $R$,

ZIKV-Zika virus.

\section{INTRODUCTION}

The two prize winning yeasts

Yeasts belong to the kingdom of fungi. The two most commonly used yeasts for virus research are budding yeast (Saccharomyces cerevisiae) and fission yeast (Schizosaccharomyces pombe). Budding yeast reproduces itself through a "budding" cell division process, i.e., a smaller daughter cell (a small bud or bleb) is initially formed on the mother cell. During mitosis, half of the chromatids are separated into the daughter cell. The bud continues to grow until it separates from the mother cell, forming a new cell [1]. In contrast, fission yeast is divided by binary fission that produces a daughter cell with equal size to the mother cell. Hence, it is referred to as "fission yeast". The budding yeast is also known as the "baker yeast" or the "brewer's yeast" because it is commonly used commercially for baking breads or making top-fermented beers such as ale. The species name of fission yeast "pombe" is derived from the Swahili word for beer (pombé). It has been used in Central Africa to make pombe beer that is similar to bottom-fermented beers such as lager. Both yeasts are classified in the phylum of Ascomycota, i.e., a group of fungi that produce ascospores during meiosis. Thus they are also known as the sac (ascus) fungi. Same as multicellular eukaryotes, they have nuclei and other membrane-bound organelles such as mitochondria, Golgi apparatus and a network of membranous tubules within the cytoplasm known as endoplasmic reticulum (ER). 
Yeasts are single cell eukaryotic organisms. Many of the fundamental cellular functions such as cell proliferation, cell cycle regulation, cellular transport, cell self-destruction of intracellular contents or programed cell death are highly conserved from yeasts to higher eukaryotes. Therefore, yeasts are in many ways good models to study some of those highly conserved cellular activities. Indeed, the study of both budding and fission yeasts in the past half century has contributed significantly to advance our knowledge in human biology, physiology and cancer biology. Those significant contributions to science are exemplified by the awarding of three Nobel Prizes to scientists who were working on yeast model systems within a time period of fifteen years. Specifically, the shared 2001 Nobel Prize in Physiology and Medicine to three scientists including yeast biologists Drs. Leland Hartwell and Paul Nurse was for their seminal discoveries concerning the control of the cell cycle by using budding and fission yeast models, respectively [2, 3]. Dr. P. Nurse used the fission yeast model system and discovered Cdc2, a human homologue of CDK1, a key regulator of all eukaryotic cell cycle. Dr. L. Hartwell used budding yeast model system and discovered the "start" gene that was found to have a central role in controlling the first step of each cell cycle. Dr. Hartwell also introduced the concept "checkpoint", a cellular surveillance system that safeguards the integrity of the cell cycle. Nearly all of the major cell cycle regulators identified in budding yeast and fission yeast have found their counterparts in mammalian cells $[4,5]$. Defects in cell cycle control cause dysregulation of cell division and proliferation that may lead to cancers. Therefore, those fundamental discoveries have a great impact on all aspects of human cell biology. The 2013 Nobel Prize in Physiology or Medicine honored three scientists including another yeast biologist Dr. Randy W. Schekman who has solved the mystery of how the cell organizes its transport system. In particular, Dr. Schekman discovered a set of Sec genes that encode key regulators of the secretory pathway, which regulates vesicle transport in the cell. The importance of using yeast as a model to study human cell biology was once again cemented by the 2016 Nobel Prize in Physiology and Medicine. It was awarded to a single scientist, Dr. Yoshinori Ohsumi, for his discoveries of mechanisms for autophagy. His groundbreaking studies illuminated by using budding yeast as a model on how cells governs this intracellular degradation pathway to balance the cellular live and death process in response to various genotoxic stresses including viral infections $[6,7]$.

There are numerous advantages of using yeasts to study heterologous gene activities over higher eukaryotes. For example, yeast cells are easy to culture in the laboratory. They grow rapidly with a doubling time of 3-5 hours. Cells producing heterologous proteins can be manipulated with various sophisticated molecular, cellular and genetic approaches. Traditional yeast genetic methods could be used to examine the gene effect in yeast on the loss-of-function by gene deletion; or on the gain-of-function by integrating a special gene of interest into the yeast chromosome. Genetic traits such as dominant or recessive phenotype of an identified cellular protein could be tested directly through haploid or diploid stages of the yeast life cycle. Finally, an identified cellular factor could also be verified by functional complementation using yeast or other eukaryotic homologues in respective cells. In fact, many human proteins that are important to human biology or diseases such as cancer-associated proteins were first discovered by studying their homologs in yeasts. For reviews of related topics, see [8-11].

There are also many benefits of using yeasts as model systems to study viruses of higher eukaryotes such as plant, animal or human viruses. The main reason is because yeasts carry their own indigenous viruses. Both positive sense $(+)$ double stranded RNA (dsRNA) viruses, $(+)$ single stranded RNA (ssRNA) viruses and retrotransposon elements have been reported in yeasts and other fungi [12, 13]. For example, studies of yeast killer viruses have helped us to study cellular necrosis and apoptosis during virushost interaction [14-17], and to understand potential cellular viral restriction factors toward viral infections $[18,19]$. Since the integration process of yeast retrotransposons resembles in many ways retroviral integration, molecular studies of fission yeast Tf elements or budding yeast Ty elements provided insights into functions of retroviruses such as HIV or murine leukemia viruses [20-22].

As shown in Table 1, many (+) RNA viruses and some DNA viruses replicate, to various degrees, in yeasts. For example, the first report showing yeast as a host for the replication of a plant viral genome was from Brome mosaic virus (BMV), which is a member of the alphavirus-like superfamily of animal and plant positive strand RNA viruses [23]. In this study, yeast expressing BMV RNA replication genes $1 a$ and $2 a$ supports RNA-dependent replication and transcription of BMV RNA3 derivatives, suggesting all cellular factors that are essential for BMV RNA replication and transcription must be present in the yeast. Price et al. [24] described the first viral genome replication of animal virus, Flock House Virus (FHV) and its de novo synthesis of infectious virions in the yeast Saccharomyces cerevisiae. Besides the RNA viruses, the genomes of multiple human papillomavirus (HPV) subtypes and bovine papillomavirus (BPV) type 1 can stably replicate in yeast in an E1 or E2independent manner as nuclear plasmids $[25,26]$. This HPV viral gene E1 is a helicase, and E2 is a transcriptional activator and plasmid maintenance factor. Both are known to contribute to the episomal replication of the viral genome [25]. This might be the first report showing an entire human viral genome can replicate as an episomal plasmid in yeast, suggesting yeast has the necessary cellular factors to support HPV/BPV replications. 
Yeasts also have much smaller genomes than higher eukaryotes. Study of higher eukaryotic viruses that replicate in yeasts could aid study of core relationship between a viral function and cellular proteins, thus avoiding high complexity and redundancy of higher eukaryotic systems. In addition, genome-wide single gene deletion yeast strain libraries and/or genomic DNA or cDNA plasmid libraries are widely available for both yeasts. Cellular factors that are involved in viral DNA replication can thus be identified by exposing the viral replication apparatus to those genomic libraries. In this case, loss or reduction of the viral replication in the absence of a cellular protein would suggest requirement or involvement of this cellular protein in viral replication. Similarly, cellular viral restriction factors could

TABLE 1. High eukaryotic viruses that replicate in yeast S. cerevisiae.

\begin{tabular}{|c|c|c|c|c|c|}
\hline Family & Virus & Genome & $\begin{array}{l}\text { Natural } \\
\text { host }\end{array}$ & $\begin{array}{l}\text { Measurement of viral replication in } \\
\text { yeast }\end{array}$ & References \\
\hline \multicolumn{6}{|l|}{ RNA viruses } \\
\hline Bromoviridae & $\begin{array}{l}\text { Brome mosaic virus } \\
\text { (BMV) }\end{array}$ & $(+)$ ssRNA & Plants & $\begin{array}{l}\text { Replication gene 1a, 2a-dependent } \\
\text { and RNA-dependent transcription and } \\
\text { replication of BMV RNA3 derivatives }\end{array}$ & [23] \\
\hline \multirow[t]{3}{*}{ Tombusviridae } & $\begin{array}{l}\text { Carnation Italian ringspot } \\
\text { virus (CIRV) }\end{array}$ & $(+)$ ssRNA & Plants & $\begin{array}{l}\text { Transcription and replication of CIRV } \\
\text { DI-72 RNA that are supported by sim- } \\
\text { ultaneous expression of two replicase } \\
\text { proteins (p36 and p95) in a three- } \\
\text { plasmid system }\end{array}$ & [30] \\
\hline & $\begin{array}{l}\text { Tomato bushy stunt virus } \\
\text { (TBSV) }\end{array}$ & $(+)$ ssRNA & Plants & $\begin{array}{l}\text { Transcription and replication of TBSV } \\
\text { DI-7 RNA that are supported by } \\
\text { simultaneous expression of two repli- } \\
\text { case proteins (p33 and p92) in a three- } \\
\text { plasmid system }\end{array}$ & [31] \\
\hline & $\begin{array}{l}\text { Cymbidium ringspot } \\
\text { virus (CRV) }\end{array}$ & $(+)$ ssRNA & Plants & Similar to CIRV and from the same lab & [32] \\
\hline \multirow[t]{2}{*}{ Nodaviridae } & $\begin{array}{l}\text { Flock House virus } \\
\text { (FHV) }\end{array}$ & $(+)$ ssRNA & Animals & $\begin{array}{l}\text { FHV genome replication and transcrip- } \\
\text { tion in FHV virion RNA-transfected } \\
\text { yeast spheroplasts; plaque formation } \\
\text { on Drosophila cell monolayers }\end{array}$ & [24] \\
\hline & $\begin{array}{l}\text { Nodamura virus } \\
\text { (NoV) }\end{array}$ & $(+)$ ssRNA & $\begin{array}{l}\text { Animals } \\
\text { (Mammals) }\end{array}$ & Similar to FHV & [28] \\
\hline Avsunviroidae & $\begin{array}{l}\text { Avocado sunblotch viroid } \\
\text { (ASBVd) }\end{array}$ & $\begin{array}{l}\text { ssRNA } \\
\text { circular }\end{array}$ & Plants & $\begin{array}{l}\text { Self-cleavage and replication of ASBVd } \\
\text { RNA strands of both polarities }\end{array}$ & [33] \\
\hline
\end{tabular}

\section{DNA viruses}

\begin{tabular}{|c|c|c|c|c|c|}
\hline \multirow[t]{2}{*}{ Papillomaviridae } & $\begin{array}{l}\text { Human papillomavirus } \\
\text { (HPV) }\end{array}$ & $\begin{array}{l}\text { dsDNA } \\
\text { circular }\end{array}$ & Humans & $\begin{array}{l}\text { Amount of HPV genome DNA using a } \\
\text { Dpnl resistance assay }\end{array}$ & {$[25]$} \\
\hline & $\begin{array}{l}\text { Bovine papillomavirus } \\
\text { (BPV) }\end{array}$ & $\begin{array}{l}\text { dsDNA } \\
\text { circular }\end{array}$ & Animals & Same as HPV & [26] \\
\hline Geminiviridae & $\begin{array}{l}\text { Mung bean yellow } \\
\text { mosaic India virus } \\
\text { (MBYMIV) }\end{array}$ & $\begin{array}{l}\text { ssDNA } \\
\text { circular }\end{array}$ & Plants & $\begin{array}{l}\text { Yeast colony size, PCR and southern } \\
\text { blot measurement of viral replicated } \\
\text { MBYMIV plasmid DNA }\end{array}$ & [29] \\
\hline Parvoviridae & $\begin{array}{l}\text { Adeno-associated virus } \\
\text { (AAV) }\end{array}$ & $\begin{array}{l}\text { ssDNA } \\
\text { circular }\end{array}$ & $\begin{array}{l}\text { Animals and } \\
\text { Humans }\end{array}$ & Similar to MBYMIV & [34] \\
\hline
\end{tabular}

Note: Modified and updated based on [27]. Note that ASBVd is a viroid not a virus per se. 
potentially be uncovered by overproduction of a genomic or cDNA plasmid library in the viral replicating yeast cells. Finally, many of the experimental approaches used in yeasts are not readily achievable in mammalian cells. For example, multiple and permanent heterologous geneproducing yeast strains can be established and maintained in the laboratory that allow simultaneous and batch testing repeatedly, thus facilitating large-scale and functional characterization of genes of interest such as a small viral genome [35, 36]. Therefore, study of virus-cell interaction by taking advantage of the simplicity, biosafety and genetic amenability of yeasts can often reveal novel scientific findings that are not always easy to discover solely by relying on high eukaryotic systems.

\section{The budding yeast (Saccharomyces cerevisiae)}

Budding yeast ( $S$. cerevisiae) has sixteen chromosomes with a genome size of approximately $1.2 \times 10^{6}$ base pairs (bps). It has about 5,700 protein-coding genes, with about $4.4 \%$ of them contain introns [37]. S. cerevisiae cells are typically round to ovoid in shape with $5-10 \mu \mathrm{m}$ in diameter. The daughter cells that are generated during cell division are generally smaller than mother cells (Fig. 1A). Unlike fission yeast, budding yeast's cell wall contains both $\beta$ glucans and chitin. The optimum temperature for growth of $\mathrm{S}$. cerevisiae is $30-35^{\circ} \mathrm{C}$. For general experimental purposes, budding yeasts are usually grown in the complete yeast extract, peptone and dextrose (YPD) medium at $30^{\circ} \mathrm{C}$ without selection. Standard synthetic defined (SD) minimal medium is used to grow auxotrophic yeast cultures or select for yeast transformants containing plasmids. The selection media are generated by adding defined mixture of amino acids, vitamins and other components known as the drop-out supplements. A list of budding yeast selectable markers HIS3, LEU2, TRP1 or URA3 are used to select for the presence of a plasmid [38]. Antibiotics such as hygromycin $B$ and kanamycin can also be used as selectable markers [39, 40].

Like other fungi, the life cycle of both budding and fission yeasts undergo asexual and sexual reproductive cycles (Fig. 1). They are generally maintained in the laboratory through vegetative growth by asexual reproduction [41]. Unlike fission yeast, budding yeast reproduces both as haplontic (haploid) and diplontic (diploid) cells during asexual life cycle by mitosis (Fig. 1A). However, under high-stress conditions such as nutrient starvation, haploid cells will die; while diploid cells undergo meiosis to form haploid spores by sporulation [42, 43]. Haploid cells of opposite mating types (a or $\alpha$ ) can go on to mate (conjugate) and to reform diploid cells [44]. Budding yeast grows and divides through an asymmetric budding process. During mitosis, the daughter cell begins to form as a small bud on the tip of the mother cell. At metaphase, one set of sister chromatids moves into the bud. Continued growth of the bud eventually becomes a separated daughter cell. Budding yeasts have all of the typical eukaryotic cell cycle stages of G1, S, G2 and M (mitosis) phases, which can be recognized by DNA content, nuclear morphology and bud morphology. Budding yeast spends most of its cell cycling in $\mathrm{G} 1$ phase, which is similar to human cell cycle. Nearly all of the major cell cycle regulators identified in budding yeast have their counterparts in mammalian cells [4]. Budding yeast has been used extensively as a model to study virus-host interactions and cellular restriction factors to viral infections [45, 46]. Genome-wide approaches have been used in budding yeast to study various virus-related activities including viral transcription, viral replication and virus-host interactions [46-50]. General reviews on these topics are available [27, $45,46,51,52]$.

\section{The fission yeast (Schizosaccharomyces pombe)}

Fission yeast (S. pombe) has three chromosomes with the size of 5.7, 4.6, and 3.5 Mb (megabases), respectively [53]. Its genome has approximately $1.4 \times 10^{6} \mathrm{bps}$. It is estimated to have about 5,000 protein-coding genes. More than $90 \%$ of them contain introns $[4,54]$. Subcellular locations of almost all fission yeast proteins are known [55]. A typical fission yeast cell is rod-shaped that is normally $3-4 \mu \mathrm{m}$ in diameter and $7-14 \mu \mathrm{m}$ in length (Fig. 1B). Fission yeast cell is unique from other ascomycetous yeasts because its cell wall lacks chitin but deposits $\alpha$-(1,3)-glucan or pseudonigeran in addition to the usual $\beta$-glucans. The optimal growth temperature for $S$. pombe cells in the laboratory is $30^{\circ} \mathrm{C}$ with a doubling time of $2-4$ hours. The most commonly used growth medium with all of the necessary nutrients is the Standard Yeast Extract with Supplements (YES) medium, which is normally used to grow fission yeast cells without selection. The Edinburgh Minimal Medium (EMM) is typically used to select for the presence of a plasmid that carries a LEU2 gene or URA4 gene to compensate cellular gene defect in the leu1-32 or ura4-294 gene. In order to select for a LEU2 or URA4-carrying plasmid, the EMM medium needs to be supplemented with leucine or uracil to complement the corresponding auxotrophic mutants of a yeast strain. Antibiotics such as cycloheximide and Zeocin have also been used to select for hygromycin and bleMX6 resistance in fission yeast cells $[56,57]$.

Fission yeast is normally present as haplontic cells but its diploid form could be triggered during meiosis by mating when cells were subject to nutritional starvation (Fig. 1B, bottom) $[11,58]$. Mating could take place between cells of two opposite mating types (heterothallic plus, $h^{+}$or heterothallic minus, $h$ ), or by self-cross of homothallic strains, e.g., $h^{90}$ that has both mating types $[8,59]$. Fusion of the two cells results in the formation of diploid zygotes. Sporulation is followed immediately by meiosis to produce four round or oval haploid ascospores that are enclosed within an ascus. When appropriate nutrients are resumed to allow cells re-entering its asexual life cycle, the ascus wall will disintegrate, and ascospores will germinate and eventually divide to form haploid clones [8,60]. The fission yeast cell maintains its shape by growing exclusively through its cell tips. After mitosis, cell division occurs by medial fission with the formation of a septum that cleaves the cell at its midpoint to produce two equal sized cells (Fig. $1 \mathrm{~B}$, top). Its specific length corresponds well with its growth phase in the cell cycle $[61,62]$, which is similar to that of other eukaryotes, and includes the G1, S, G2, and 

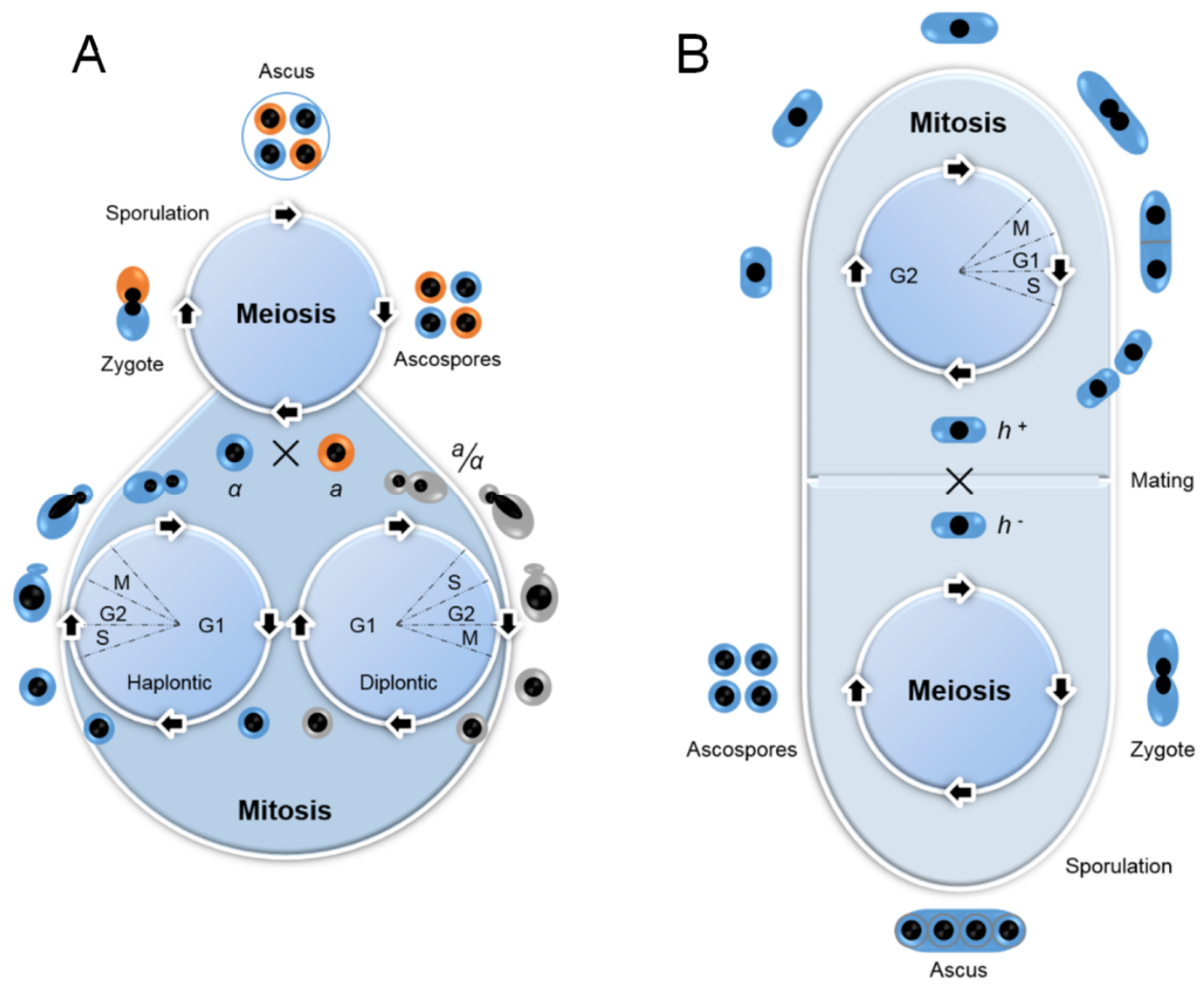

FIGURE 1: Life cycles of budding yeast (Saccharomyces cerevisiae) (A) and fission yeast (Schizosaccharomyces pombe) (B). Diagrams show yeasts have both asexual (vegetative) and sexual reproductive cycles, respectively. (A) Budding yeast is generally maintained in the laboratory through vegetative growth both as haplontic (haploid) and diplontic (diploid) cells during asexual life cycle by mitosis, which produce daughter cells by budding off of mother cells. Mitotic cell cycle has all of the typical eukaryotic cell cycle stages of G1, S, G2 and $\mathrm{M}$ phases, but it spends most of its cell cycling in $\mathrm{G1}$ phase, which is similar to human cell cycle. Under stressful conditions, diploid cells undergo meiosis to form haploid spores by sporulation. Haploid cells of opposite mating types (a or $\alpha$ ) can go on to mate (conjugate) and to reform diploid cells. (B) Fission yeast is normally present as haploid cells through mitosis. Cells are divided equally between daughter and mother cells. In contrast to budding yeast cell cycle, fission yeast spends most of its cell cycling in G2 phase. Its diploid form could be triggered by stress through mating of opposite mating type $\left(h^{+}\right.$or $\left.h^{-}\right)$during meiosis.

M phases. However, S. pombe contains an extended G2 phase that can make up as much as $75 \%$ of its cell cycle [61]. In addition, the fission yeast nuclear envelope remains intact throughout mitosis. Therefore, all transactions involving the chromosomes during this phase occur within the nucleus.

Fission yeast has been used extensively to study cell cycle regulation, DNA damage and repair as well as DNA replication. For example, like budding yeast, nearly all of the major cell cycle regulators identified in fission yeast have their counterparts in mammalian cells $[4,5]$. It has also been used as a host system to study virus-host interactions including the effect of viral proteins on cell cycle regulation $[63,64]$, gene expression, cell death and apoptosis [65-67]. In addition, fission yeast has been used to carry out largescale and functional characterization of small viral genomes such as human immunodeficiency virus type 1
(HIV-1) and Zika virus (ZIKV) [55, 68-70]. General reviews on some of the related topics have been published previously [11, 22, 64, 71-74].

In summary, either fission yeast or budding yeast could be used as a reasonable model for the study of various viral activities and virus-host interactions. They often complement to each other in many ways. However, from the evolution perspective, these two yeasts diverged approximately 300 to 600 million years ago $[75,76]$. Consequently, both yeasts have homologous genes with higher eukaryotes that they do not necessarily share with each other. Thus, it is important to know that there are sufficient functional differences between these two yeasts that sometimes could yield conflict results. For example, $96 \%$ of the fission yeast genes contain introns; whereas only $4 \%$ of the budding yeast gene carries introns $[4,37,54]$. Similarly, fission yeast has RNAi machinery genes like those in vertebrates, but it 
is missing from budding yeast [77]. Conversely, S. cerevisiae has well-developed peroxisomes, while S. pombe does not. Another example is that budding yeast has an extended G1 phase of the cell cycle. Thus, the G1-S transition is tightly controlled; whereas fission yeast spends most of its cell cycling time in the $\mathrm{G} 2$ phase of the cell cycle. Hence, the G2-M transition is under tight control Therefore, the budding yeast might be a better choice to study cell cycle G1-S transition, whereas the fission yeast could serve a preferable role in the study of cell cycle G2-M regulation. Therefore, careful consideration has to be taken before choosing a model organism to study the viral genes of your interest. In the following sections, special emphasis is given to those studies that have generated significant discovery toward the understanding of a viral function or the virus-host interactions by using either yeast as a model system.

\section{INDIGENOUS YEAST VIRUSES}

Yeasts have their own indigenous viruses. The budding yeast viruses include three families of dsRNA viruses ( $L-A$, $L-B C$, and $M$ ), two families of ssRNA viruses ( $T$ and $W$ ), and five families of retrotransposons (Ty1 - Ty5) $[12,13]$. The fission yeast includes retrovirus-like retrotransposons (Tf1 and Tf2) $[78,79]$. Among those yeast viruses, the dsRNA and ssRNA viruses are infectious, as they are able to infect other healthy yeast cells, and to transmit themselves from cell to cell. As results of the yeast infection, some of those infectious yeast strains kill their receptive cells. Thus, they are also known as killer yeast. Historically, the final realization that the killer yeasts are actually associated with their own indigenous viruses took more than a century [80]. Briefly, Louis Pasteur initially described the contribution of microbes to spoilage of beers in 1866 [81]. Horace Brown later linked the beer spoilage to Saccharomyces yeasts [82] Although it was known for quite a while that some yeast strains kill other yeast cells, the term "killer" yeast was first proposed by Wood and colleagues in 1968 [83]. The killer yeast strains secrete protein toxins (K1, K2, K28 and Klus) that are lethal to non-killer strains of the same or other species [84]. Another synonyms term "zymocide" was also introduced in 1983 by Young et al. [85] to indicate that this killer yeast is only lethal to yeasts and not to bacteria or higher organism. Two dsRNA viruses were subsequently discovered in the killer yeast strains [86]. Those two dsRNA viruses are the $S$. cerevisiae L-A virus (ScV-LA) and the $M$ virus (ScV-M), respectively [87, 88]. However, not until 1987, El-Sherbeini and co-workers [12] demonstrated that yeast killer viruses are capable of extracellular transmissions. It was previously thought that killer yeast viruses transmit by cytoplasmic mixing during cell division, mating or other induced forms of cell fusion. Extracellular transmission was demonstrated by direction infection of $\mathrm{K} 1$ and K2 killer viral preparations to yeast spheroplasts, competent yeast cells by lithium acetate, or to mating cells [12]. It is now known that the killing effect is achieved by the copresence of ScV-LA and ScV-M viruses within the same yeast strain. Typically, these two viruses coevolve. Different SCV-M viruses could pair with a ScV-LA virus to form a unique yeast killer strain $[87,88]$. The helper virus, ScV-LA, encodes the capsids for both viruses; and the K1, K2, K28, and Klus toxins are produced by different satellite ScV-M viruses $[87,88]$. Therefore, the presence of a ScV-M dsRNA virus needs co-existence of a ScV-LA helper virus.

An interesting effect of the yeast killing effects is that, besides causing necrosis, they also induce apoptotic programed cell death by triggering caspase- or oxidative stress-mediated apoptosis [89]. This apoptotic effects is seen during yeast viral infection of the receptive cells. Interestingly, however, the killer yeast cells themselves are immune to the toxic effects presumably due to intrinsic immunity [90]. A set of yeast chromosomal gene products, SKI1, SKI2, SKI3, SKI6, SKI7, and SKI8, prevent the ScV-LA virus and its satellite ScV-M viral RNAs from harming their own cells $[91,92]$. Thus, yeasts have been used to study cell apoptosis during virus-host interaction [14-17], and to understand potential cellular viral restriction factors toward viral infections $[18,19]$.

Another intriguing fact is that the ScV-LA virus has two open reading frames (ORFs). The 5 ' gag gene encodes the major coat Gag protein, and the 3' pol gene encodes a multifunctional Pol protein that includes a RNA-dependent RNA polymerase (RdRP). The Gag-Pol fusion protein is produced by a minus-1 (-1) ribosomal frameshift during translation, a process that is identical to that used by higher retroviruses [92]. Because of the functional similarities of the minus-1 translational ribosomal frameshift between yeast dsRNA viruses and that of higher eukaryotes [92], it provides a useful tool to delineate molecular actions of viral replication of higher eukaryotic retroviruses such as HIV, which is described in the next section.

\section{YEAST FOR THE STUDY OF VIRAL FUNCTIONS}

A list of higher eukaryotic viruses that are known to replicate in yeast $S$. cerevisiae is included in Table 1 . Those viruses include plant, animal and human viruses. Both RNA viruses and DNA viruses, including some of those pathologically important human viruses such as HPV, were found to replicate, in various degrees, in yeast. Those (+) RNA viruses share some common features during their viral life cycle, e.g., 1) the same viral (+)ssRNA genome serves both as messenger RNA (mRNA) for viral protein translation, and as a viral template for viral duplication, 2) translated viral proteins recruit viral genome to form a viral replication complex (VRC) on intracellular membranes in association with cellular proteins, 3) all (+)ssRNA viruses encode a RdRP for the synthesis of viral RNA template to form a dsRNA intermediate, and 4) special host cell proteins, such as RNA-binding proteins, chaperone proteins, and membrane remodeling or lipid synthesis proteins, are required that collectively participate in the coordination of navigating through intracellular membrane-associated secretory pathways for viral replication [93].

A number of experimental tools could or have been used in yeasts to study life cycle of (+)ssRNA viruses, e.g., 1) an entire viral RNA genome could be transcribed from yeast plasmids and transfected into yeast cells [94, 95], 2) both viral RdRP and cellular proteins could be provided 
in-trans to test for their roles in viral replication [96], and 3) yeast genomic and CDNA libraries as well as the genomewide gene knock-out libraries were used to study virus-cell interactions [24, 28, 46, 97]. By using those sophisticated experimental tools, significant progress has been made in the past several decades to understand the basic aspects of viral life cycle and replication especially those viral steps including translation of viral protein, synthesis of viral genomic template, and association of viral proteins with cellular proteins that are required for viral replication. A number of detailed reviews on these subjects are available $[27,45,46,64,74,94]$. In the following section, specific examples are given in each of those categories.

\section{Minus-1 ribosomal frameshifting in HIV-1 viral protein translation}

The (-1) ribosomal frameshifting is commonly found in many of the RNA viruses including HIV-1 and SARS coronavirus (SARS-CoV). This programed translational frameshifting is a viral mechanism to merge proteins encoded by two overlapping ORFs such as Gag and Pol. The HIV-1 frameshifting site consists of a slippery sequence (U $\underline{\text { UUU }}$ UUA), followed by a stimulatory element P3 $[98,99]$. It is part of a larger three-helix structure of the viral RNA genome. The stimulatory element and the slippery sequence pairs with an upstream region to form the second helix. Studies on the HIV-1 frameshifting in the yeast $S$. cerevisiae have contributed significantly to our understanding of this process. In particular, yeast viruses such as the ScV-LA virus also use frameshifting to produce its own viral proteins, a process that is identical to that used by higher retroviruses [92].

A HIV-1 frameshifting yeast model was first established by Wilson and co-workers [100] who produced the Gag-Pol fragment containing the potential frameshifting site of HIV1 from a yeast expression plasmid. In this way, they were able to monitor the production of the frameshifted protein by western blot analysis. Because of the low efficiency of frameshifting events, initially they failed to identify the stimulatory element. Thus, it was believed that no secondary structure was present in the HIV slippery site $[98,100]$. However, the stimulatory element was later revealed by NMR [101]. A follow-up yeast study by using a dual reporter system indeed confirmed a direct correlation between HIV frameshifting efficiency and presence of the stimulatory element as a stem loop [102]. Subsequently, it was shown that a number of retroviruses including HIV-1 have the same stimulatory element. Together, studies of slippage efficiencies of the HIV frameshifting site in vivo in yeast and in vitro in a mammalian system have demonstrated that this process is essential for viral replication and the molecular mechanisms of frameshifting is conserved from yeast to humans [103]. Hence, with in-depth understanding of this -1 frameshifting process, it is possible to design specific antiviral drugs by introducing nonsense mutations. For example, alteration of frameshifting frequency or artificial introduction of translational stop by a drug during translational frameshifting could either reduce viral infectivity or halt viral replication $[103,104]$. There- fore, understanding of the -1 ribosomal frameshifting during translation of viral proteins in yeast provided insights into the molecular mechanism of HIV-1 viral replication.

\section{Initiation of geminivirus replication}

Besides (+) RNA viruses, yeasts have also been used to study viral replication of DNA viruses. They include double stranded DNA (dsDNA) viruses such as human and bovine papillomaviruses (HPVs and BPVs), as well as single stranded DNA (ssDNA) viruses such as Geminiviruses. They all replicate, with various degrees, in yeast (Table 1$)$ [27, 29]. Geminivirus is the largest Geminiviridae family of plant viruses with more than 300 species. Some of the wellstudied geminiviruses include African cassava mosaic virus (ACMV), maize streak virus (MSV) and Indian mungbean yellow mosaic virus (IMYMV). These viruses are responsible for significant crop damages worldwide [105]. A geminiviral genome consists of either one or two circular ssDNA in the range of 2,500 - 3,100 nucleotides. For the geminivirus with two viral genomic DNA molecules, aka the DNA-A and the DNA-B molecules [106], the DNA-A genome encodes six viral proteins, and the DNA-B produces two movement proteins [107]. Although proteins produced by both viral components are involved in viral replication, only the replication-associated protein (Rep) is indispensable for viral replication [108].

Geminiviruses do not have their own DNA polymerases and associated DNA synthesis machinery. They rely on host cellular DNA synthesis machinery to duplicate themselves via a dsDNA intermediate. During the rolling circle replication, Rep serves as a multitasking protein. It involves in viral DNA cleavage and joining after one round of replication. It also has ATPase and helicase activities [109]. Since some plant cells are terminally differentiated cells, Rep is responsible for reigniting plant cell cycling by pushing cells from cell cycle G1 phase to $S$ phase where cellular DNA synthesis apparatus is reactivated [110]. To achieve this goal, Rep binds to plant homologue of mammalian retinoblastoma protein to promote the G1-S transition [111]. In this way, Rep reactivates host cell $S$ phase gene transcription and provides a favorable environment for geminivirus replication $[110,112,113]$.

Studies of geminivirus DNA replication in both yeasts have contributed to our understanding toward the initiation of DNA replication in these groups of higher plant viruses. For example, similar to the role of Rep in plants, the MSV Rep also binds to the maize plant retinoblastoma related-protein (pRbR) protein as it does in plants [114]. This allows in-depth functional analysis of the Rep-pRbR interaction in yeast. Indeed, three nucleotide mutations in the MSV Rep-pRbR interaction motif abolished this interaction in yeast and resulted in significant reduction of MSVinduced symptom severity in maize [115]. Interestingly, one of the three mutations $C(601) A$ reversed with high frequency in the maize plant, suggesting the functional requirement and selection pressure of the Rep-pRbR interaction during MSV viral replication. Similar to budding yeast, Rep showed very similar activities in fission yeast as it does in plants. For example, ectopic expression of the 
ACMV Rep alone triggers cellular DNA re-replication in fission yeast [109]. Especially, it showed its characteristic DNA cleavage activity, activated DNA synthesis and increased cellular DNA contents without cell division [109]. Furthermore, a RXL motif was identified in the Rep protein that might be an alternative link to the Rep-pRbR interaction and cell cycle control [116]. Mutation in this motif abrogated Rep-induced DNA re-replication in fission yeast. Consistent with the fission yeast finding, the ACMV containing the same mutation in the Rep motif was unable to induce symptomatic infection in tobacco (Nicotiana benthamiana) plants [116].

\section{Genomic approach to study involvement of cellular proteins in viral replication of tomato bushy stunt virus (TBSV)}

Genome-wide approaches have been applied to study viral replication of a number of plant, animal and human viruses. Reviews or reports that cover these topics can be found at $[24,28,46,97]$. For example, TBSV is a (+)ssRNA virus that infects various crops including tomatoes [46, 94]. The TBSV genome contains five genes that encode a replicase composed of two proteins ( $\mathrm{p} 33$ and p92), a capsid protein (called CP or p41), a RNA silencing suppressor p19 and a movement protein p22 [117]. The TBSV replication can be measured in yeast by a three-plasmid TBSV replicon system [95]. Two of the plasmids constitutively express the essential TBSV replicase proteins, p33 and p92; the third plasmid drives TBSV replicon's transcription through an inducible GAL1 promoter. The TBSV replication is measured by the transcription of the TBSV replicon RNA after induction with galactose, which accumulate at very high level in the wildtype yeast strain [94]. A number of genomic and proteomic methods were used to identify yeast cellular proteins that are involved in TBSV replication. For a detailed review of this topic, see [46]. In brief, a single gene yeast knock-out (YKO) library was first subjected to a genome-wide screening and revealed 96 genes whose absence either inhibited or stimulated TBSV viral replication [95]. Because the YKO library only contains deletions of non-essential genes, additional tests were carried out in a Tet promoter-inducible yTHC library, and a temperature-sensitive ( $t s)$ essential gene library with a total of about 800 genes in each library. Thirty and 101 additional TBSV replication regulators were found, respectively $[118,119]$. By using a reversed approach, a genomic plasmid library containing most of the yeast ORFs $(\sim 5,500)$ were overproduced in a TBSV repliconcontaining yeast strain. A total of 141 proteins were identified. Among them, 40 proteins increased and the remainder decreased the accumulation of TBSV replicon RNA [119]. A total of 36 overlapping yeast proteins were identified based on previous screens of other viruses. A conserved protein kinase $\mathrm{C} 1$ ( $\mathrm{Pkc} 1$ ) that was shown to inhibit TBSV replication was chosen to validate their results. Indeed, a ts mutant of Pkc1 led to a high level of TBSV replication, supporting the idea that Pkc1p is an inhibitor of TBSV RNA replication. Consistently, a specific Pkc1p inhibitor, cercosporamide, also resulted in increased TBSV replication in yeast, plant cells, and in whole plants, confirming that Pkc1 and its associated pathways are involved in regulation of TBSV replication [119].

\section{YEAST FOR UNDERSTANDING VIRUS-HOST INTERACTIONS Virus-mediated cell cycle regulation}

Viruses typically encode a limited number of proteins. They have to rely on host cellular resources to complete their life cycle. Thus, they will take a variety of devious approaches to create a cellular environment for the benefit of their own reproduction [120]. One common viral strategy is to subvert host cell cycle into a specific phase of the cell cycle where the virus gains maximal benefit. For example, many dsDNA viruses such as HPV and SV40 infect quiescent cells. After infection, they drive cells to $S$ phase of the cell cycle where the pool of deoxynucleotides is high, thus providing an environment that is conducive to viral DNA synthesis [121]. A similar viral action was also noted in ssDNA viruses such as geminiviruses that drive cell cycle G1-S transition [110, 112, 113]. Other viruses such as HIV-1 and herpes simplex viruses (HSV) induce cell cycle arrest. The possible objective is to avoid competition of cellular resources between the virus and the normal host cellular metabolism [122]. Additional benefits to virus-induced cell cycle arrest could include avoiding host antiviral immune responses, maximizing availability of the cellular resources for its transcription, translation and assembly, and delaying programmed cell death until completion of the viral replication [123-125].

Other viral proteins that regulate cell cycle in yeasts include SV40 RF-S [126], HIV-1 viral protein R (Vpr) [127, 128], HTLV-1 Tax [129], HPV E2 [130], TBSV Rep [112], and ZIKV proteins [36]. In the followings, HIV-1 Vpr is used as an example to illustrate how fission yeast was used to delineate molecular mechanism of Vpr-induced cell cycle $\mathrm{G} 2$ arrest. For extensive reviews of this topic, see [63, 64, 72]. Note that expression of HIV-1 vpr gene in budding yeast resulted in cell growth arrest. It, however, did not induce cell cycle $\mathrm{G} 2$ arrest as it was shown in mammalian and fission yeast cells $[127,131,132]$.

HIV-1 Vpr is a virion-associated viral protein of about $12.7 \mathrm{kD}$. Its function is required both in vitro and in vivo for efficient viral infection of non-dividing mammalian cells such as monocytes and macrophages [133-135]. It is a multifaceted protein that is involved in multiple steps of the HIV-1 life cycle [136]. It involves in cytoplasmic-nuclear transport of proviral integration complex (PIC), activates HIV-1 LTR (long terminal repeat) promoter for viral transcription, and induces cell death through apoptosis [136]. In addition, it induces cell cycle G2 arrest in both human and fission yeast cells, suggesting a highly conserved activity of this viral protein [128, 134, 137]. Vpr-induced cell cycle G2 arrest in host CD4(+) T-cells was thought to avoid host immune response [138]. It was also shown that HIV-1 in cells that arrested in the $\mathrm{G} 2$ phase of the cell cycle by $\mathrm{Vpr}$ replicates at its maximum level [139].

Cell cycle G2-M transition is a tightly regulated cellular process that requires activation of the Cdc2 kinase (a human homologue of CDK1), which determines onset of mitosis in all eukaryotic cells. In both human and fission yeast 
cells, the activity of Cdc2/CDK1 is regulated in part by the phosphorylation status of tyrosine 15 (Tyr15) on Cdc2/CDK1, which is phosphorylated by Wee1 kinase during late $\mathrm{G} 2$ and is rapidly dephosphorylated by the $\mathrm{Cdc} 25$ tyrosine phosphatase to trigger cellular entry into mitosis. These mitotic Cdc2/CDK1 regulators are safeguarded by two well-characterized mitotic checkpoint pathways to prevent cells from entering mitosis when cellular DNA is either damaged (the DNA damage G2 checkpoint pathway) or when DNA replication is compromised (the DNA replication checkpoint pathway) [63, 140, 141].

HIV-1 Vpr induces cell cycle G2 arrest by subverting the same cell cycle G2-M regulatory apparatus as described above. Specifically, it promotes hyper-phosphorylation of Tyr15 of Cdc2/CDK1 in mammalian and fission yeast cells $[128,142]$. The inhibitory effect on Cdc2/CDK1 is achieved by inhibition of the Cdc25 phosphatase and activation of the Wee1 kinase [143-145]. Subsequent studies in mammalian cells showed that Vpr-induced G2 arrest is mediated through direct binding of Vpr with a Vpr-binding protein (VprBP) [146, 147], which is part of the ubiquitin E3 enzyme, suggesting possible involvement of the ubiquitin proteasome system. Indeed, $\mathrm{Vpr}$ associates with the proteasome both in fission yeast and mammalian cells [148]. Specifically, in fission yeast, it associates with the 19S subunit of the proteasome through 19S-associated Mts4 and Mts2 proteins. This Vpr-19S proteasome interaction was further confirmed in mammalian cells where $\mathrm{Vpr}$ associates with the same two mammalian orthologues (Mts4 and S5a) of the fission yeast proteins [148]. In addition, Rhp23, a fission yeast homologue of human DNA excision repair protein hHR23A and budding yeast RAD23, was shown to be critical for Vpr-proteasome interaction and was involved in the Vpr action [149, 150]. Interestingly, even though both ATM and ATR were shown participating in Vprinduced $\mathrm{G} 2$ arrest, implicating involvement of mitotic DNA damage or DNA replication checkpoint pathways [151, 152] neither of these two classic mitotic checkpoint control pathways was exclusively responsible for the G2 arrest induced by Vpr. Further fission yeast and mammalian studies showed that $\mathrm{Vpr}$ induces $\mathrm{G} 2$ arrest via a protein phosphatase 2A (PP2A)-mediated cellular pathway [145, 153, 154]. Unlike the conventional cell cycle G2-M regulation, $\mathrm{Vpr}$ also induces cell cycle $\mathrm{G} 2$ arrest at least in part through a mechanism involving in a fission yeast kinase Srk1 and its human homologue MK2 [69]. These results suggest that $\mathrm{Vpr}$ might modulate cell cycle G2 transition through an alternative and possibly a novel cellular mechanism other than the classic mitotic checkpoints $[63,72,155]$. Indeed, a later study showed that Vpr induces cell cycle G2 arrest through a unique molecular mechanism that regulates host cell cycle regulation in an S-phase dependent fashion [156]. Altogether, this example demonstrates that fission yeast can indeed be used as a reliable model organism to dissect molecular mechanism of HIV-1 Vpr-induced cell cycle G2 arrest. It was the combined results generated from the fission yeast model system with the study and verification in mammalian cells that led to the finding that Vpr induces cell cycle G2 arrest through a unique virus-mediated cellular mechanism.

\section{Virus-mediated cell death and apoptosis}

Viral infection could cause cell death through at least three different ways in yeasts and higher eukaryotes, i.e., necrosis, apoptosis or autophagy-mediated cell death [157]. Necrosis is a form of cell death that is caused by factors external to the cell such as viral infection, which results in the unregulated digestion of cell components. In contrast, apoptosis is a naturally occurring and programmed process of cellular death. Autophagy is a normal cellular process that maintains cellular homeostasis. It regulates protein degradation and turnover of the destroyed cell organelles. In response to cellular stress such as nutrient starvation or viral infection, autophagy is activated. However, prolonged activation of autophagy often results in autophagymediated cell death by either cell necrosis or apoptosis. Thus, autophagy and cell death are regulated balance of two cellular events.

The processes of yeast cell death resemble in many ways those of higher eukaryotes [158-161]. Thus, yeast could serve as model organism to study these terminal cellular processes. For example, yeast has been used as a model to study yeast necrosis. In contrary to the traditional belief that necrosis is normally a passive cell dying process, evidence accumulated over more than a decade suggests there is actually a regulated necrotic program that controls how long a cell will live (longevity) or die [16]. As for yeast apoptosis, there was long skepticism as whether yeast has true apoptosis. However, this cynicism starts to dissipate by the increasing evidence generated from yeast studies in the past two decades. In particular, like in mammalian cells, yeast apoptosis is also mediated through a caspasemediated proteolytic process in addition to other characteristic apoptotic features [162-164]. In fact, some of the same mammalian pro-apoptotic or anti-apoptotic regulators were found in yeasts that show similar activities to higher eukaryotes. For detailed reviews of this subject, see $[158,161,165-168]$. Although yeast apoptosis is not as well studied in fission yeast as in budding yeast, an apoptoticlike process does seem to be present in fission yeast [169]. For instance, expression of mammalian pro-apoptotic proteins Bax and Bak induce apoptosis-like cell death that was strongly suppressed by co-expression of the anti-apoptotic protein $\mathrm{Bcl}-\mathrm{XL}[170,171]$. A pombe caspase 1 (Pca1) was identified and its budding yeast homologue Yca1p was shown to be a bona fide caspase [172]. Moreover, both caspase-dependent and -independent processes are present in fission yeast $[172,173]$. Therefore, at least some of the mammalian apoptotic processes are present in yeasts.

Yeast killer strains that carry (+)dsRNA viruses or produce viral toxins induce yeast apoptosis in sensitive or targeted non-infected yeast cells [89]. Such yeast-mediated apoptosis typically occurs at low-to-moderate concentration of viral toxins in those cells; whereas necrotic cell death takes place at high concentration, suggesting activation of apoptotic or necrotic cellular death regulators 
requires different thresholds of stimuli. The viral toxins such as the pore-forming proteins, $\mathrm{K} 1, \mathrm{~K} 2$, and zygocin, kill yeast cells by disrupting the cytoplasmic membrane; the protein toxins such as $\mathrm{K} 28$ induce cell cycle $\mathrm{G} 1 / \mathrm{S}$ cell cycle arrest and thereby block DNA synthesis in the nucleus [89].

Expression of exogenous viral proteins also induce cell death and apoptosis in yeasts $[64,174]$. Viral proteins that induced yeast cell death and apoptosis include, but are not limited to, pro-apoptotic proteins such as adenovirus E4orf4 protein [175], HIV-1 Vpr [67, 176], HIV-1 protease (PR) [177-180], and ZIKV proteins [36]. Anti-apoptotic viral proteins include baculovirus p35 [174] and DPV022 protein of the Deerpox virus [181]. In the followings, we present two HIV-1 viral proteins ( $\mathrm{Vpr}$ and $\mathrm{PR}$ ) as examples to demonstrate how studies on virus-mediated yeast cell death and apoptosis were carried out in budding and fission yeast.

HIV-1 PR is an essential viral enzyme. Its primary function is to proteolyze the viral Gag-Pol polyprotein for production of viral enzymes and structural proteins as well as for maturation of infectious viral particles. HIV-1 PR induces cell death/apoptosis presumably due to its ability to proteolyze vital host cellular proteins [177, 182-184]. The coupling between PR-induced cell death/apoptosis and proteolysis was demonstrated by the fact that HIV-1 PR inhibitors (PIs) prevent PR-induced cell death/apoptosis [183-186]. HIV-1 PR induces apoptosis in mammalian cells by caspase- 3 cleavage and interruption of mitochondrial functions [178, 187]. Similar to its cell death/apoptotic effect in mammalian cells, HIV-1 PR also induces cell death in both budding and fission yeast $[35,177]$. Those cell killing effects were caused by HIV-1 PR proteolytic activities because HIV-1 PIs also suppressed PR-induced cell killing in both yeasts [179, 180, 188]. Interestingly, however, HIV-1 PR kills budding yeast resulting in cell lysis; whereas no cell lysis was observed in fission yeast. The difference between these two yeasts could potentially be explained, at least in part, by the relative thicker cell wall of fission yeast than budding yeast [179, 180]. Studies in the fission yeast further demonstrated that HIV-1 PR cleaves its indigenous viral protein target sequences such as matrix and p6 proteins $[189,190]$. Moreover, PR-induced cell death triggered the reactive oxidative species (ROS) production, an indication of oxidative stress. It also caused changes in mitochondrial morphology that are linked to apoptosis $[67,191]$. Together, those data suggested that HIV-1 PR displays the same enzymatic activity as it does during HIV-1 infection of mammalian cells. In order to explore the molecular interactions of HIV-1 PR with cellular proteins, a genome-wide screen was launched to search multicopy HIV-1 PR suppressors using a fission yeast genomic cDNA library in HIV-1 PR-producing fission yeast cells. A fission yeast serine/threonine kinase (Hhp2) was identified as a novel PR suppressor that suppresses HIV-1 PR-induced PR protein cleavage and cell death in fission yeast [179]. Significantly, Hhp2 kinase suppressed, at least in part, HIV-1 PR-induced cell death and apoptosis in mammalian cells [179].
$\mathrm{Vpr}$ also induces cell death in budding and fission yeast [128, 192]. HIV-1 Vpr-induced cell death/apoptosis contributes to the depletion of CD4 T-cells in HIV-infected patients [193]. Further characterization of Vpr-induced cell death in budding yeast showed that the C-terminal domain of $\mathrm{Vpr}$ is primarily responsible for the cell killing effect in yeast and mammalian cells $[194,195]$. When the Cterminal Vpr was subject to intact mammalian cells or purified mitochondria, it induced apoptosis through a permeability transition pore complex (PTPC) of mitochondria [176]. Consistently, yeast strains lacking part of the PTPC showed reduced Vpr-induced killing than the wildtype control cells.

Similar to Vpr-induced apoptosis in mammalian cells, Vpr triggers ROS production, promotes phosphatidylserine externalization and induces hyperpolarization of mitochondria in fission yeast, leading to changes of mitochondrial membrane potential [67]. These data suggested that HIV-1 Vpr-induced cell death in fission yeast is reminiscent of apoptosis. To further explore Vpr-fission yeast cell interaction during $\mathrm{Vpr}$-induced cell death/apoptosis, a genomewide functional search for multicopy protein suppressors of Vpr-induced cell death/apoptosis was conducted by overproducing a fission yeast cDNA library in a Vprproducing fission yeast strain. A novel anti-apoptotic protein, translational elongation factor 2 (EF2) was isolated [66]. It not only suppresses Vpr-induced cell death in fission yeast but it also suppresses $\mathrm{Vpr}$-induced apoptosis in mammalian cells through caspase 9 and caspase 3mediated mechanism $[66,67]$.

\section{Functional characterization of small viral genomes in fission yeast}

As described in the previous sections, yeasts have proven to be fruitful hosts to conduct genome-wide studies on virus-host interactions, particularly because their small genomes and genetic amenability. For the same token, yeast could also, in principle, serve as a surrogate to carry out functional study of small viral genomes. It is conceivable that effects of single or multiple viral gene products could be tested separately or simultaneously in the same yeast strain, thus allowing testing the same basic cellular function that is affected by individual or combination of different viral proteins. Besides all of the operational and genetic advantages of using yeast as a model organism, a large-scale gene cloning strategy and a streamlined functional characterization system are also needed for this purpose. Example of such a fission yeast system is shown in Fig. $2[68,70]$. Please note that there is nothing new in the molecular features of these shuttle vectors. Goal of Fig. 2 is to illustrate the combined use of these vectors will provide a robust and streamlined shotgun strategy of a small viral genome. Thus, notable features of this fission yeast system include 1) the gene cloning process is streamlined to a sequential order to add or remove the green fluorescent protein (GFP) tag. For example, molecular cloning of a viral gene into one of the $\mathrm{pYZ3N}$-GFP-carrying vectors generates a 5' GFP-tagged viral protein that can be used for the determination of its subcellular localization; the pYZ1N gene expression vector and its derivatives are used for 
functional characterization of a viral protein without the GFP tag; 2) all of the gene cloning is done in an unidirectional fashion with positive identification of the gene insertions, based on $\alpha$-complementation of X-gal in Escherichia coli; 3 ) an inducible gene transcriptional no message in the thiamine (nmt1) promoter $[68,196]$ is used to allow measurement of the viral gene-specific effect; 4) three different strengths of the nmt1 promoter (high, intermediate and low) with two different cell growth selection markers (leu2 and ura4) $[68,196]$ allow testing of gene expression at various levels or testing of viral protein-to-protein interactions $[68,196]$; and 5) multiple viral gene-producing yeast strains can be established and maintained that allow simultaneous viral gene testing, thus facilitating functional characterization of a small viral genome. By using this system, functions of small viral genomes such as HIV-1 or ZIKV have been characterized as outlined below [35, 36].

The HIV-1 RNA genome is about $9 \mathrm{~kb}$ that encode a total of nine ORFs including Gag, Pol and Env polyproteins, four accessory proteins (Vpu, Vif, Vpr, Nef) and two regulatory proteins (Rev, Tat). In a genome-wide and functional analysis of the HIV-1 genome in fission yeast, each one of the HIV-1 genes was cloned and expressed individually in a wild type fission yeast strain [35]. The effect of protein expression on basic cellular functions such as subcellular location, cell proliferation, and cytotoxicity were observed. Overall, there is a general correlation of subcellular localization of each viral protein between fission yeast and mammalian cells. Three viral proteins, Vpr, PR and Rev, affected various cellular activities. Only the Rev effect is described below as the effects of HIV-1 Vpr and PR have already been described in the early sections.

HIV-1 Rev is an $18 \mathrm{kD}$ phosphoprotein with 116 amino acids that contains a nuclear localization signal (NLS) and nuclear export signal (NES) $[197,198]$. It mediates nuclear export of partially spliced and un-spliced viral transcripts through its NES allowing nucleocytoplasmic shuttling, thus playing a pivotal role in viral replication [199, 200]. It interacts with a small nucleoporin-like protein hRIP/RAB1 and yRip1p in mammalian and budding yeast, respectively [201, 202]. Consistent with the role of Rev in nucleocytoplasmic shuttling, Rev localizes predominantly in the fission yeast nucleus with minor presence in the cytoplasm [35]. In addition, production of HIV-1 Rev protein appeared to reduce cellular growth in fission yeast and mammalian cells, but this sluggish cellular growth did not lead to cell death. Paradoxically, however, Rev causes death in non-dividing human cells [200]. Further tests revealed that Rev triggered transient ROS production. This result suggested that the fission yeast cells were likely experiencing transient intracellular oxidative stress. Typically, constant induction of oxidative stress should produce large and persistent amounts of ROS that should have caused cell death [203, 204]. Thus, the observed differences in patterns of ROS production could potentially explain why Rev induces cell death in non-dividing human cells but not in proliferating yeast cells [200].

Another and the most recent example of using fission yeast to carry out large-scale molecular cloning and
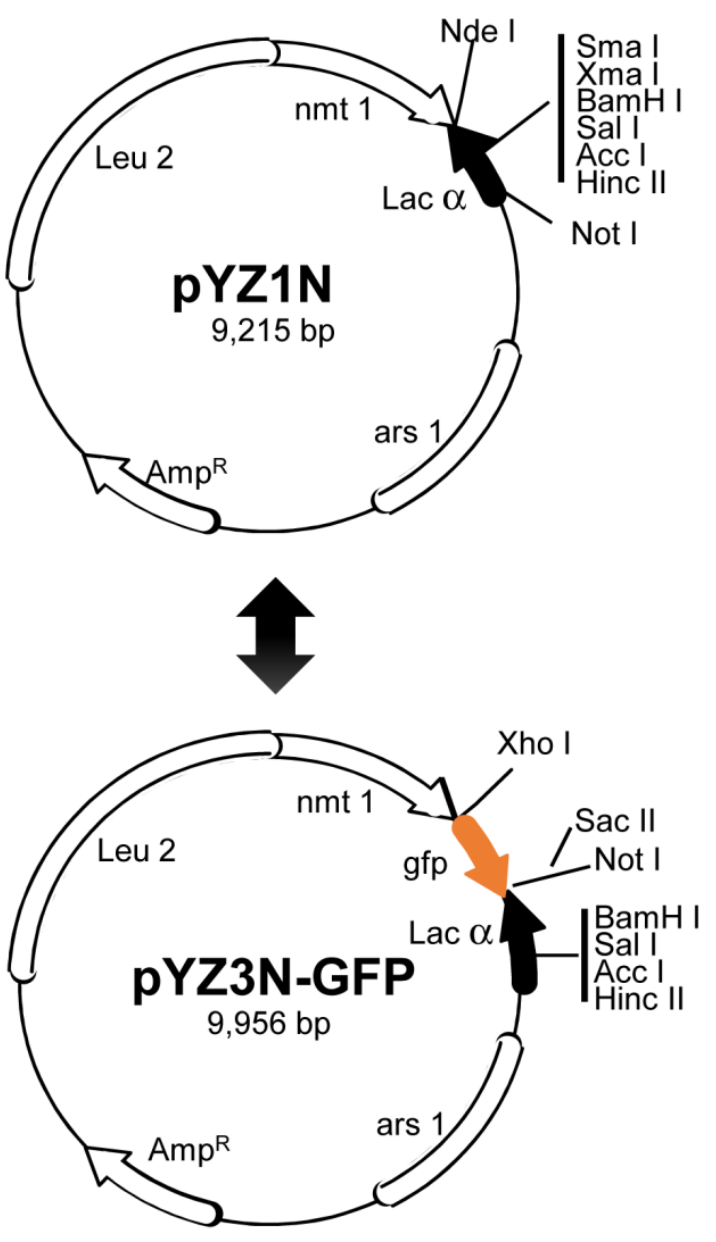

FIGURE 2: Schematic diagram of a shotgun approach to clone a small viral genome in fission yeast. (Top) The pYZ1N vector contains a wild type $n m t 1$ promoter $[68,196]$. It carries a LEU2 gene for selection. pYZ2N contains the wild type $n m t 1$ promoter and a URA4 gene selection marker. (Bottom) pYZ3N-GFP contains the same $n m t 1$ promoter as $\mathrm{pYZ1N}$ and has an added green fluorescent protein GFP tag. The $\alpha$-peptide of $\beta$-galactosidase is used for selecting DNA inserts with $\alpha$-complementation. Unique cloning sites in these vectors are indicated. ars1, origin of replication from S. pombe; Leu2, Saccharomyces cerevisiae leucine biosynthesis gene; AmpR, bacterial ampicillin resistance gene. Adapted from $[36,68]$. Note that nothing is new in molecular features of shuttle vectors described. Goal of this figure is to illustrate a robust and streamlined strategy of shotgun gene cloning of a small viral genome.

functional characterization of a small viral genome is the study of the ZIKV [36]. ZIKV was thought to be a mild virus that had limited threat to human health. However, the most recent ZIKV outbreak in the Americas surprised us because of its rapid global spread and the discovery that ZIKV causes severe neurologic disorders or birth defects including microcephaly and the Guillain-Barré syndrome [205-208]. So the question is why the ZIKV suddenly has become so virulent in humans? ZIKV infection studies in human brain and neural progenitor cells suggested that 
ZIKV conferred various cytopathic effects (CPEs) including reduced neural cell proliferation, cell cycle dysfunction and increased cell death/apoptosis [209, 210]. Those CPEs correlated with the neuronal cell-layer volume of the brain organoids resembling microcephaly, suggesting ZIKVinduced microcephaly is high likely the result of ZIKVmediated increase of CPEs [205-207, 211]. The next and logic question is which ZIKV viral protein(s) is responsible for the observed increase of CPEs? To address this question in a timely manner, fission yeast was used as a surrogate to embark on a rapid genome-wide analysis of ZIKV proteins [36]. Fission yeast is particularly useful here because those ZIKV-mediated CPEs are high likely conserved cellular activities $[2,6,212]$.

ZIKV is a small (+)ssRNA virus that has a viral genome of approximately $10.7 \mathrm{~kb}$ [213]. The ZIKV genome encodes a single polyprotein that is cleaved by viral and host proteases into 14 proteins and small peptides, i.e., six structural (anaC $\rightarrow C, \operatorname{PrM} \rightarrow M, \operatorname{Pr}$ and $E$ ), seven nonstructural (NS1, NS2A, NS2B, NS3, NS4A, NS4B and NS5) proteins and a small peptide $2 \mathrm{~K}[36,214]$. Each one of the 14 ZIKV viral cDNA that encodes a specific protein product was cloned into the fission yeast gene expression systems (Fig. 2) [68]. All of the ZIKV viral activities were measured simultaneously under the same inducible conditions thus it expedited the functional characterization of the ZIKV genome. Consistent with the notion that ZIKV is a cellular membraneassociated virus and ER is the major "viral factory" [215217], 9 out of the 14 ZIKV proteins associated with the ER network, including nuclear membrane, ER to Golgi apparatus [215, 217, 218]. Seven ZIKV proteins (five structural proteins and two non-structural proteins) conferred some of the same CPEs as reported in the ZIKV-infected mammalian cells $[36,205,209,211,215]$. Specifically, they also restricted cellular growth, triggered cellular autophagy, caused cell cycle dysfunction and cell death [36]. Consistently, some of the same ZIKV protein effects such as NS4A have already been reported in human cells [219]. For example, NS4A triggers autophagy in human fetal neural stem cells through inhibition of the mammalian TOR pathway via AKT [219]. In fission yeast, five ZIKV proteins including NS4A triggered autophagy as indicated by the formation of yeast cytoplasmic puncta [36, 220]. Further analysis showed that NS4A activates autophagy through the cellular TOR stress pathway that connects NS4Amediated oxidative stress and the ROS production. Fission yeast study further showed that the inhibitory NS4A effect on TOR was mediated through Tor1 and Tip41, which are the human equivalents of TSC1 and TIP41 proteins [221, 222]. Altogether, these yeast findings provide a foundation for future research of viral cytopathic factors that contribute to the increase of viral pathogenicity and possibly the induction of microcephaly [223].

\section{YEAST FOR DRUG DISOCVERY}

Yeast as a cell-based high-throughput system for the discovery of small molecule antiviral drugs

Small molecule antiviral drugs could be very effective as in treating e.g, HCV or HIV infections. In these two cases, the antivirals could cure HCV infection or eliminate the HIV virus to non-detectable levels [224, 225]. However, currently, there are very limited number of antiviral drugs on the market to fight for other major and clinically important viral infections such as influenza, hepatitis $B$ virus (HBV) and ZIKV. Moreover, emerging drug resistance is also a major concern [180, 226-228]. Therefore, there are urgent and constant needs to develop new and better antiviral drugs.

Research and development of a new US FDA-approved drug takes on average of at least ten years with a total cost of more than one billion of US dollars [229]. Even with such a long time period and high cost, the average success rate of a lead drug candidate that reaches to its final approval is approximately one out of ten thousands [230]. Majority of the lead compounds failed because of the drug cytotoxicity or drug associated adverse side effect. Hence, it is always desirable to develop a fast, large-scale and cost-effective drug discovery process that, at the end, could generate a drug that is target-specific and less toxic.

Cell-based and high throughput drug screening (HTS) systems could be used to for the new drug discovery. The advantages of a cell-based assay include 1) cytotoxic compounds are automatedly removed from the HTS drug screenings, 2) the drug screening could be designed against a heterologous gene target, thus it is target-specific, and 3) unlike the structure-based drug designs, cell-based drug screening is functionally driven. Thus, it has the potential to identify novel inhibitors such as allosteric inhibitors, i.e., an inhibitor that inhibits the viral target activity regardless of whether it binds to the target as the structure-based design does. Yeasts offer additional advantages over the use of mammalian cell systems. For example, yeast cells grow much faster than mammalian cells and they are very easy to maintain in a large-scale setting. Thus, it is more cost-effective than using mammalian cells. Yeasts are also genetically amendable for stable gene expression by integrating the viral gene of interest into yeast chromosomes. Inducible expression of the target gene-of-interest further allows target-specific drug screening. Another and important benefit is that yeast is non-infectious to humans. Altogether, yeasts offer a rapid, cost-effective and nonbiohazardous HTS system for the discovery of noncytotoxic, target-specific and possible novel class of antiviral drugs.

Both fission and budding yeast have been used to develop HTS for the discovery of antiviral drugs, which include HIV-1 [10, 231, 232], CMV [233], Epstein-Barr virus [234], SARS-CoV [235] and influenza virus [236]. For example, CMV PR is an essential viral enzyme for viral replication. Inhibition of this vital enzyme by CMV inhibitors suppresses CMV viral replication [233, 237]. A budding yeast cellbased system was developed by inserting the CMV PR cleavage sequence into the yeast Trp1p isomerase gene [234]. Inactivation of the Trp1p by CMV PR-mediated cleavage of Trp1p causes cell growth arrest. Thus, when the CMV PR activity is inhibited by a CMV PR inhibitor such as $\mathrm{BI} 131$ or $\mathrm{B} \mid 36$, yeast cells restore normal cellular growth [234]. 
Another budding yeast cell-based HTS assay was for the Matrix-2 (M2) proton channel protein of the influenza A virus [236]. The M2 proton channel is a homotetramer that is an integral part of the viral envelope, hence it is essential for viral replication. A similar growth restoration assay was developed as expression of $\mathrm{M} 2$ inhibits yeast cell growth. Thus, the M2 proton channel was used as an anti-influenza drug target. HTS screening of 150,000 compounds yielded 21 anti-M2 inhibitors including the known M2 inhibitors of amantadine and rimantadine [238].

Fission yeast has also been used for the development of antiviral HTS against HIV-1 Vpr and PRs [179, 180, 232]. In the case of HIV-1 Vpr, its activities are associated with increase of viral replication and depletion of CD4 T-lymphocytes, a hallmark of HIV-1 infection. Slow disease progression with low viral load has also been linked to Vprdefective viral infections in rhesus monkeys, chimpanzees or HIV-infected patients [239-243], suggesting Vpr could potentially be used as a new drug target for anti-HIV therapies. In addition, Vpr prevents cell proliferation, induces cell cycle $\mathrm{G} 2 / \mathrm{M}$ arrest and causes cell death both in fission yeast and mammalian cells [63, 64, 244], thus providing separate and unique cellular endpoints to set up the primary, second and counter-screen assays that are typically required for the HTS drug screening. Since Vpr blocks cell growth and induces cell death and apoptosis, an absorbance-based assay measuring $\mathrm{Vpr}$-induced growth arrest was used as the primary assay. Automated fluorescent detection of Vpr-induced cell death by the yeast live/dead assay was used as a secondary assay. Production of GFP driven by the same $n m t 1$ promoter as the primary and secondary assays was used as a counter-screen assay to eliminate potential false positives due to the inhibitory activity against the $n m t 1$-mediated transcription [232]. This HTS platform was used to screen against more than 400,000 of small molecule compounds at the National Chemical Genomic Center of the National Institute of Health, USA. A total of 165 lead compounds were found to have various levels of inhibitory activities against Vpr. Among them, three clusters of chemical compounds were identified.

A fission yeast cell-based assay was also developed for HIV-1 PR [35, 179]. HIV-1 PR is a major therapeutic target in antiretroviral therapies (ARTs) because it is an essential viral enzyme [231]. Indeed, HIV-1 PI is currently the most potent class of anti-HIV drugs. Monotherapy with $\mathrm{PI}$ alone can reduce HIV-1 viral load by several logs [245]. Besides HIV-1 PR-induced yeast cell death, HIV-1 PR also functions as a proteolytic enzyme in fission yeast in the same manner as it does in mammalian cells $[35,177]$. It cleaves the same indigenous HIV-1 viral p6/MA protein substrate as it does during natural HIV-1 infections. Moreover, both PRinduced cell death and proteolytic cleavages can be prevented by PR-specific enzymatic inhibitors, Indinavir (IDV), Darunavir (DRV) and other PIs [179, 180]. Most interestingly, multi-PI resistant HIV-1 PRs, which were isolated directly from HIV-1 infected patients, also showed the same viral activities in fission yeast. In addition, those multi-PI resistant PRs retained the same drug resistant profiles in the fission yeast as they do in mammalian cells [180]. This opens up a unique opportunity to use fission yeast as surrogate system to develop HTS systems against HIV-1 superbugs that are resistant to many, if not all, of the existing protease inhibiting drugs [180, 226, 227].

Note that fission yeast has a thick cell wall. Thus, there certainly are differences in cell membrane permeability and drug uptakes between yeast and human cells. Generally, much higher drug concentration than that used in mammalian cells is required in fission yeast to achieve the same inhibitory effect of a viral target. However, this should not be a functional concern because HIV-1 PIs such as IDV, DRV and others effectively inhibited the same HIV-1 PRs in a dose-dependent manner as they do in mammalian cells $[179,180]$. Nevertheless, the effective inhibitory concentration of an inhibitory compound identified from yeast must be re-calibrated when it is used in testing of mammalian cells.

\section{CONCLUDING REMARKS}

Both budding and fission yeast have been used as model systems for the study of plants, animal and human viruses in the past century. There is no doubt that, through those yeast studies, significant progress has been made toward our understanding of those viruses and their interactions with cellular proteins. However, we should also be mindful that, after all, yeasts are not plants, animals or humans. Any new findings from the yeast models must be verified in their respective hosts. Therefore, it is important to know the limitation of yeasts as they may not be suitable to study every aspect of the virus. For example, budding yeast should not be the preferred choice to study mRNA processing or siRNA because only a small percentage of yeast protein-coding genes contain introns, nor does it have a comparable siRNA process with higher eukaryotes. Similarly, fission yeast should not be used to study peroxisomes. However, both yeasts are well-suited to study cell cycle regulation and some aspects of the programed cell death. It is also worthwhile mentioning again that the use of yeasts as a model tool saves cost, and provides unique tools to identify highly conserved cellular factors that interact with the virus of interest. In particular, when the use of yeast to study virus is combined with the tools of higher eukaryotic biology and virology, it will empower us with a unique set of tools. Such a distinctive combination of tools could give rise to unique perspectives of scientific findings that are otherwise difficult to obtain based solely on a single approach or organism.

\section{ACKNOWLEDGMENTS}

The author would like to thank Dr. Ge Li for critical reading and discussion of this manuscript. This work was supported in part by an intramural fund from the University of Maryland Medical Center and NIH grants (R01 GM127212-01A1 and R21 Al129369-01.

\section{CONFLICT OF INTEREST}

The author declares no conflict of interests. 


\section{COPYRIGHT}

(C) 2017 Zhao. This is an open-access article released under the terms of the Creative Commons Attribution (CC BY) license, which allows the unrestricted use, distribution, and reproduction in any medium, provided the original author and source are acknowledged.

\section{REFERENCES}

1. Yeong FM (2005). Severing all ties between mother and daughter: cell separation in budding yeast. Mol Microbiol 55(5): 1325-1331.

2. Nurse $P$ (2002). Cyclin dependent kinases and cell cycle control (nobel lecture). Chembiochem 3(7): 596-603.

3. Hartwell L (2001). Interview: Leland Hartwell, PhD, Nobel Prize for Medicine winner. MedGenMed 3(4): 3.

4. Wixon J (2002). Featured organism: Schizosaccharomyces pombe, the fission yeast. Comp Funct Genomics 3(2): 194-204.

5. Wood V, Gwilliam R, Rajandream MA, ...., Nurse P (2002). The genome sequence of Schizosaccharomyces pombe. Nature 415(6874): 871-880.

6. Tooze SA, Dikic I (2016). Autophagy Captures the Nobel Prize. Cell 167(6): 1433-1435.

7. Levine B, Klionsky DJ (2017). Autophagy wins the 2016 Nobel Prize in Physiology or Medicine: Breakthroughs in baker's yeast fuel advances in biomedical research. Proc Natl Acad Sci U S A 114(2): 201 205.

8. Zhao Y, Lieberman HB (1995). Schizosaccharomyces pombe: a model for molecular studies of eukaryotic genes. DNA Cell Biol 14(5): 359371.

9. Madeo F, Engelhardt S, Herker E, Lehmann N, Maldener C, Proksch A, Wissing S, Frohlich KU (2002). Apoptosis in yeast: a new model system with applications in cell biology and medicine. Curr Genet 41(4): 208-216.

10. Mager WH, Winderickx J (2005). Yeast as a model for medical and medicinal research. Trends Pharmacol Sci 26(5): 265-273.

11. Hoffman CS, Wood V, Fantes PA (2015). An Ancient Yeast for Young Geneticists: A Primer on the Schizosaccharomyces pombe Model System. Genetics 201(2): 403-423.

12. El-Sherbeini M, Bostian KA (1987). Viruses in fungi: infection of yeast with the K1 and K2 killer viruses. Proc Natl Acad Sci U S A 84(12): 4293-4297.

13. Wickner RB (1989). Yeast virology. FASEB J 3(11): 2257-2265.

14. Cheng WC, Leach KM, Hardwick JM (2008). Mitochondrial death pathways in yeast and mammalian cells. Biochim Biophys Acta 1783(7): 1272-1279.

15. Madeo F, Carmona-Gutierrez D, Ring J, Buttner S, Eisenberg T, Kroemer $\mathrm{G}$ (2009). Caspase-dependent and caspase-independent cell death pathways in yeast. Biochem Biophys Res Commun 382(2): 227231.

16. Carmona-Gutierrez D, Jungwirth $\mathrm{H}$, Eisenberg $\mathrm{T}$, Madeo $\mathrm{F}$ (2010). Cell cycle control of cell death in yeast. Cell Cycle 9(20): 4046.

17. Lin SJ, Austriaco N (2014). Aging and cell death in the other yeasts, Schizosaccharomyces pombe and Candida albicans. FEMS Yeast Res 14(1): 119-135.

18. Sasvari Z, Alatriste Gonzalez P, Nagy PD (2014). Tombusvirus-yeast interactions identify conserved cell-intrinsic viral restriction factors. Front Plant Sci 5:383.
Please cite this article as: Richard Yuqi Zhao (2017). Yeast for virus research. Microbial Cell 4(10): 311-330. doi: 10.15698/mic2017.10.592

19. Rowley PA, Ho B, Bushong S, Johnson A, Sawyer SL (2016). XRN1 Is a Species-Specific Virus Restriction Factor in Yeasts. PLoS Pathog 12(10): e1005890.

20. Rausch JW, Miller JT, Le Grice SFJ (2017). Reverse Transcription in the Saccharomyces cerevisiae Long-Terminal Repeat Retrotransposon Ty3. Viruses 9(3).

21. Levin HL, Moran JV (2011). Dynamic interactions between transposable elements and their hosts. Nat Rev Genet 12(9): 615-627.

22. Esnault C, Levin HL (2015). The Long Terminal Repeat Retrotransposons Tf1 and Tf2 of Schizosaccharomyces pombe. Microbiol Spectr 3(4).

23. Janda $M$, Ahlquist $P$ (1993). RNA-dependent replication, transcription, and persistence of brome mosaic virus RNA replicons in S. cerevisiae. Cell 72(6): 961-970.

24. Price BD, Rueckert RR, Ahlquist $P$ (1996). Complete replication of an animal virus and maintenance of expression vectors derived from it in Saccharomyces cerevisiae. Proc Natl Acad Sci U S A 93(18): 94659470 .

25. Angeletti PC, Kim K, Fernandes FJ, Lambert PF (2002). Stable replication of papillomavirus genomes in Saccharomyces cerevisiae. J Virol 76(7): 3350-3358.

26. Zhao K-N, Frazer IH (2002). Replication of bovine papillomavirus type 1 (BPV-1) DNA in Saccharomyces cerevisiae following infection with BPV-1 virions. J Virol 76(7): 3359-3364.

27. Alves-Rodrigues I, Galao RP, Meyerhans A, Diez J (2006). Saccharomyces cerevisiae: a useful model host to study fundamental biology of viral replication. Virus Res 120(1-2): 49-56.

28. Price BD, Eckerle LD, Ball LA, Johnson KL (2005). Nodamura virus RNA replication in Saccharomyces cerevisiae: heterologous gene expression allows replication-dependent colony formation. J Virol 79(1): 495-502.

29. Raghavan V, Malik PS, Choudhury NR, Mukherjee SK (2004). The DNA-A component of a plant geminivirus (Indian mung bean yellow mosaic virus) replicates in budding yeast cells. J Virol 78(5): 24052413.

30. Pantaleo V, Rubino L, Russo M (2003). Replication of Carnation Italian ringspot virus defective interfering RNA in Saccharomyces cerevisiae. J Virol 77(3): 2116-2123.

31. Panavas T, Nagy PD (2003). Yeast as a model host to study replication and recombination of defective interfering RNA of Tomato bushy stunt virus. Virology 314(1): 315-325.

32. Rubino L, Navarro B, Russo M (2007). Cymbidium ringspot virus defective interfering RNA replication in yeast cells occurs on endoplasmic reticulum-derived membranes in the absence of peroxisomes. J Gen Virol 88(Pt 5): 1634-1642.

33. Delan-Forino C, Maurel M-C, Torchet C (2011). Replication of avocado sunblotch viroid in the yeast Saccharomyces cerevisiae. J Virol 85(7): 3229-3238. 
34. Cervelli T, Backovic A, Galli A (2011). Formation of AAV single stranded DNA genome from a circular plasmid in Saccharomyces cerevisiae. PloS one 6(8): e23474.

35. Nkeze J, Li L, Benko Z, Li G, Zhao RY (2015). Molecular characterization of HIV-1 genome in fission yeast Schizosaccharomyces pombe. Cell Biosci 5:47.

36. Li G, Poulsen M, Fenyvuesvolgyi C, Yashiroda Y, Yoshida M, Simard JM, Gallo RC, Zhao RY (2017). Characterization of cytopathic factors through genome-wide analysis of the Zika viral proteins in fission yeast. Proc Natl Acad Sci U S A 114(3): E376-E385.

37. Kupfer DM, Drabenstot SD, Buchanan KL, Lai H, Zhu H, Dyer DW, Roe BA, Murphy JW (2004). Introns and splicing elements of five diverse fungi. Eukaryot Cell 3(5): 1088-1100.

38. Jones JS, Prakash L (1990). Yeast Saccharomyces cerevisiae selectable markers in pUC18 polylinkers. Yeast 6(5): 363-366

39. Kaster KR, Burgett SG, Ingolia TD (1984). Hygromycin B resistance as dominant selectable marker in yeast. Curr Genet 8(5): 353-358.

40. Walker ME, Gardner JM, Vystavelova A, McBryde C, de Barros Lopes $M$, Jiranek $V$ (2003). Application of the reuseable, KanMX selectable marker to industrial yeast: construction and evaluation of heterothallic wine strains of Saccharomyces cerevisiae, possessing minimal foreign DNA sequences. FEMS Yeast Res 4(3): 339-347.

41. Balasubramanian MK, Bi E, Glotzer M (2004). Comparative analysis of cytokinesis in budding yeast, fission yeast and animal cells. Curr Biol 14(18): R806-818.

42. Herskowitz I (1988). Life cycle of the budding yeast Saccharomyces cerevisiae. Microbiol Rev 52(4): 536-553.

43. Katz Ezov T, Chang SL, Frenkel Z, Segre AV, Bahalul M, Murray AW, Leu JY, Korol A, Kashi Y (2010). Heterothallism in Saccharomyces cerevisiae isolates from nature: effect of $\mathrm{HO}$ locus on the mode of reproduction. Mol Ecol 19(1): 121-131.

44. Neiman AM (2005). Ascospore formation in the yeast Saccharomyces cerevisiae. Microbiol Mol Biol Rev 69(4): 565-584.

45. Lista MJ, Voisset C, Contesse MA, Friocourt G, Daskalogianni C, Bihel F, Fahraeus R, Blondel M (2015). The long-lasting love affair between the budding yeast Saccharomyces cerevisiae and the Epstein-Barr virus. Biotechnol J 10(11): 1670-1681

46. Nagy PD, Pogany J, Lin JY (2014). How yeast can be used as a genetic platform to explore virus-host interactions: from 'omics' to functional studies. Trends Microbiol 22(6): 309-316.

47. Serviene E, Shapka N, Cheng CP, Panavas T, Phuangrat B, Baker J, Nagy PD (2005). Genome-wide screen identifies host genes affecting viral RNA recombination. Proc Natl Acad Sci U S A 102(30): 1054510550.

48. Mazurkiewicz P, Tang CM, Boone C, Holden DW (2006). Signaturetagged mutagenesis: barcoding mutants for genome-wide screens. Nat Rev Genet 7(12): 929-939.

49. Serviene E, Luksa J, Orentaite I, Lafontaine DL, Urbonavicius J (2012). Screening the budding yeast genome reveals unique factors affecting K2 toxin susceptibility. PLoS One 7(12): e50779.

50. Barajas D, Xu K, Sharma M, Wu CY, Nagy PD (2014). Tombusviruses upregulate phospholipid biosynthesis via interaction between p33 replication protein and yeast lipid sensor proteins during virus replication in yeast. Virology 471-473(72-80.

51. Roth JF (2000). The yeast Ty virus-like particles. Yeast 16(9): 785 795.

52. Morita E, Sundquist WI (2004). Retrovirus budding. Annu Rev Cell Dev Biol 20(395-425.
53. Fan JB, Chikashige $Y$, Smith $C L$, Niwa $O$, Yanagida $M$, Cantor $C R$ (1989). Construction of a Not I restriction map of the fission yeast Schizosaccharomyces pombe genome. Nucleic Acids Res 17(7): 28012818.

54. Wilhelm BT, Marguerat S, Watt S, Schubert F, Wood V, Goodhead I, Penkett CJ, Rogers J, Bahler J (2008). Dynamic repertoire of a eukaryotic transcriptome surveyed at single-nucleotide resolution. Nature 453(7199): 1239-1243.

55. Matsuyama A, Arai R, Yashiroda Y, Shirai A, Kamata A, Sekido S, Kobayashi $Y$, Hashimoto A, Hamamoto M, Hiraoka Y, Horinouchi S, Yoshida M (2006). ORFeome cloning and global analysis of protein localization in the fission yeast Schizosaccharomyces pombe. Nat Biotechnol 24(7): 841-847.

56. Burland TG, Pallotta D, Tardif MC, Lemieux G, Dove WF (1991). Fission yeast promoter-probe vectors based on hygromycin resistance. Gene 100:241-245

57. Benko Z, Zhao RY (2011). Zeocin for selection of bleMX6 resistance in fission yeast. Biotechniques 51(1): 57-60.

58. Davey J (1998). Fusion of a fission yeast. Yeast 14(16): 1529-1566.

59. Crandall $M$ (1978). Mating-type interactions in yeasts. Symp Soc Exp Biol 32:105-120.

60. Egel R, Kohli J, Thuriaux $P$, Wolf $K$ (1980). Genetics of the fission yeast Schizosaccharomyces pombe. Annu Rev Genet 14:77-108.

61. Mitchison JM, Nurse P (1985). Growth in cell length in the fission yeast Schizosaccharomyces pombe. J Cell Sci 75:357-376.

62. Alfa C, Fantes P, Hyams J, McLeod M, Warbrick E (1993). Nutritional control of entry into stationary phase determined by flow fluorocytometry. Experiments with Fission Yeast, A Laboratory Course Manual. Cold Spring Harbor Laboratory, Cold Spring Harbor, N.Y.; pp 186.

63. Zhao RY, Elder RT (2005). Viral infections and cell cycle G2/M regulation. Cell Res 15(3): 143-149.

64. Zhao Y, Elder RT (2000). Yeast perspectives on HIV-1 VPR. Front Biosci 5:D905-916.

65. Iordanskiy S, Zhao Y, Dubrovsky L, lordanskaya T, Chen M, Liang D, Bukrinsky M (2004). Heat shock protein 70 protects cells from cell cycle arrest and apoptosis induced by human immunodeficiency virus type 1 viral protein R. J Virol 78(18): 9697-9704.

66. Zelivianski S, Liang D, Chen M, Mirkin BL, Zhao RY (2006). Suppressive effect of elongation factor 2 on apoptosis induced by HIV-1 viral protein R. Apoptosis 11(3): 377-388

67. Huard S, Chen M, Burdette KE, Fenyvuesvolgyi C, Yu M, Elder RT, Zhao RY (2008). HIV-1 Vpr-induced cell death in Schizosaccharomyces pombe is reminiscent of apoptosis. Cell Res 18(9): 961-973.

68. Zhao Y, Elder RT, Chen M, Cao J (1998). Fission yeast expression vectors adapted for positive identification of gene insertion and green fluorescent protein fusion. Biotechniques 25(3): 438-440, 442, 444.

69. Huard S, Elder RT, Liang D, Li G, Zhao RY (2008). Human immunodeficiency virus type $1 \mathrm{Vpr}$ induces cell cycle G2 arrest through Srk1/MK2-mediated phosphorylation of Cdc25. J Virol 82(6): 2904 2917.

70. Li G, Zhao RY (2017). Molecular Cloning and Characterization of Small Viral Genome in Fission Yeast. In: Teresa L. Singleton, PhD, editor. Methods in Molecular Biology. Springer; in press.

71. Buchkovich K, Dyson N, Whyte P, Harlow E (1990). Cellular proteins that are targets for transformation by DNA tumour viruses. Ciba Found Symp 150:262-271; discussion 271-268. 
72. Elder RT, Benko Z, Zhao Y (2002). HIV-1 VPR modulates cell cycle $\mathrm{G} 2 / \mathrm{M}$ transition through an alternative cellular mechanism other than the classic mitotic checkpoints. Front Biosci 7:d349-357.

73. Zhao RY, Bukrinsky M, Elder RT (2005). HIV-1 viral protein R (Vpr) \& host cellular responses. Indian J Med Res 121(4): 270-286.

74. Andreola ML, Litvak S (2012). Yeast and the AIDS virus: the odd couple. J Biomed Biotechnol 2012:549020.

75. Sipiczki M (2000). Where does fission yeast sit on the tree of life? Genome Biol 1(2): REVIEWS1011.

76. Behringer MG, Hall DW (2015). Genome-Wide Estimates of Mutation Rates and Spectrum in Schizosaccharomyces pombe Indicate CpG Sites are Highly Mutagenic Despite the Absence of DNA Methylation. G3 (Bethesda) 6(1): 149-160.

77. Billmyre RB, Calo S, Feretzaki M, Wang X, Heitman J (2013). RNAi function, diversity, and loss in the fungal kingdom. Chromosome Res 21(6-7): 561-572.

78. Teysset L, Dang VD, Kim MK, Levin HL (2003). A long terminal repeat-containing retrotransposon of Schizosaccharomyces pombe expresses a Gag-like protein that assembles into virus-like particles which mediate reverse transcription. J Virol 77(9): 5451-5463.

79. Sehgal A, Lee CY, Espenshade PJ (2007). SREBP controls oxygendependent mobilization of retrotransposons in fission yeast. PLoS Genet 3(8): e131.

80. Stewart GG, Russell I (1986). One hundred years of yeast research and development in the brewing industry. Journal of Institute of Brewing 92:537-538.

81. Pasteur L (1866). Etudes sur le Vin. Imprimenss Imperials - Gauthier-Villars/ Masson, Paris.

82. Brown HT (1916). Reminiscences of fifty years' experience of the application of scientific method to brewing practice. Journal of Institute of Brewing 22:265-354.

83. Woods DR, Bevan EA (1968). Studies on the nature of the killer factor produced by Saccharomyces cerevisiae. J Gen Microbiol 51(1) 115-126.

84. Bostian KA, Elliott Q, Bussey H, Burn V, Smith A, Tipper DJ (1984). Sequence of the preprotoxin dsRNA gene of type I killer yeast: multiple processing events produce a two-component toxin. Cell 36(3): 741-751.

85. Young TW, Yagiu M (1978). A comparison of the killer character in different yeasts and its classification. Antonie Van Leeuwenhoek 44(1): 59-77.

86. Bevan EA, Herring AJ, Mitchell DJ (1973). Preliminary characterization of two species of dsRNA in yeast and their relationship to the "killer" character. Nature 245(5420): 81-86.

87. Wickner RB (1996). Double-stranded RNA viruses of Saccharomyces cerevisiae. Microbiol Rev 60(1): 250-265

88. Rodriguez-Cousino N, Esteban R (2017). Relationships and Evolution of Double-Stranded RNA Totiviruses of Yeasts Inferred from Analysis of L-A-2 and L-BC Variants in Wine Yeast Strain Populations. Appl Environ Microbiol 83(4)

89. Schmitt MJ, Reiter J (2008). Viral induced yeast apoptosis. Biochim Biophys Acta 1783(7): 1413-1417.

90. Breinig F, Sendzik T, Eisfeld K, Schmitt MJ (2006). Dissecting toxin immunity in virus-infected killer yeast uncovers an intrinsic strategy of self-protection. Proc Natl Acad Sci U S A 103(10): 3810-3815.

91. Schmitt MJ, Breinig F (2006). Yeast viral killer toxins: lethality and self-protection. Nat Rev Microbiol 4(3): 212-221.
92. Wickner RB, Fujimura T, Esteban R (2013). Viruses and prions of Saccharomyces cerevisiae. Adv Virus Res 86:1-36.

93. Nagy PD, Wang RY, Pogany J, Hafren A, Makinen K (2011). Emerging picture of host chaperone and cyclophilin roles in RNA virus replication. Virology 411(2): 374-382.

94. Galao RP, Scheller N, Alves-Rodrigues I, Breinig T, Meyerhans A, Diez J (2007). Saccharomyces cerevisiae: a versatile eukaryotic system in virology. Microb Cell Fact 6:32.

95. Panavas T, Serviene E, Brasher J, Nagy PD (2005). Yeast genomewide screen reveals dissimilar sets of host genes affecting replication of RNA viruses. Proc Natl Acad Sci U S A 102(20): 7326-7331.

96. Quadt R, Ishikawa M, Janda $M$, Ahlquist $P$ (1995). Formation of brome mosaic virus RNA-dependent RNA polymerase in yeast requires coexpression of viral proteins and viral RNA. Proc Natl Acad Sci U S A 92(11): 4892-4896.

97. Naito T, Kiyasu Y, Sugiyama K, Kimura A, Nakano R, Matsukage A Nagata K (2007). An influenza virus replicon system in yeast identified Tat-SF1 as a stimulatory host factor for viral RNA synthesis. Proc Nat Acad Sci U S A 104(46): 18235-18240.

98. Jackson DA, Yuan J, Cook PR (1988). A gentle method for preparing cyto- and nucleo-skeletons and associated chromatin. J Cell Sci 90 (Pt 3):365-378

99. Watts JM, Dang KK, Gorelick RJ, Leonard CW, Bess JW, Jr., Swanstrom R, Burch CL, Weeks KM (2009). Architecture and secondary structure of an entire HIV-1 RNA genome. Nature 460(7256): 711716.

100. Wilson W, Braddock M, Adams SE, Rathjen PD, Kingsman SM, Kingsman AJ (1988). HIV expression strategies: ribosomal frameshifting is directed by a short sequence in both mammalian and yeast systems. Cell 55(6): 1159-1169.

101. Staple DW, Butcher SE (2003). Solution structure of the HIV-1 frameshift inducing stem-loop RNA. Nucleic Acids Res 31(15): 43264331.

102. Bidou L, Stahl G, Grima B, Liu H, Cassan M, Rousset JP (1997). In vivo HIV-1 frameshifting efficiency is directly related to the stability of the stem-loop stimulatory signal. RNA 3(10): 1153-1158.

103. Bidou L, Rousset JP, Namy O (2010). Translational errors: from yeast to new therapeutic targets. FEMS Yeast Res 10(8): 1070-1082.

104. Hung M, Patel P, Davis S, Green SR (1998). Importance of ribosomal frameshifting for human immunodeficiency virus type 1 particle assembly and replication. J Virol 72(6): 4819-4824

105. Moffat AS (1999). Geminiviruses Emerge as Serious Crop Threat. Science 286(5446): 1835.

106. Stanley J, Gay MR (1983). Nucleotide sequence of cassava latent virus DNA. Nature 301:260-262.

107. Etessami P, Saunders K, Watts J, Stanley J (1991). Mutational analysis of complementary-sense genes of African cassava mosaic virus DNA A. J Gen Virol 72 (Pt 5):1005-1012.

108. Hanley-Bowdoin L, Elmer JS, Rogers SG (1990). Expression of functional replication protein from tomato golden mosaic virus in transgenic tobacco plants. Proc Natl Acad Sci U S A 87(4): 1446-1450.

109. Kittelmann K, Rau P, Gronenborn B, Jeske H (2009). Plant geminivirus rep protein induces rereplication in fission yeast. J Virol 83(13):

110. Hanley-Bowdoin L, Settlage SB, Robertson D (2004). Reprogramming plant gene expression: a prerequisite to geminivirus DNA replication. Mol Plant Pathol 5(2): 149-156.

111. Ach RA, Durfee T, Miller AB, Taranto P, Hanley-Bowdoin L, Zambryski PC, Gruissem W (1997). RRB1 and RRB2 encode maize 
retinoblastoma-related proteins that interact with a plant D-type cyclin and geminivirus replication protein. Mol Cell Biol 17(9): 50775086.

112. Gutierrez C (2000). DNA replication and cell cycle in plants: learning from geminiviruses. EMBO J 19(5): 792-799.

113. Gutierrez C, Ramirez-Parra E, Mar Castellano M, Sanz-Burgos AP, Luque A, Missich R (2004). Geminivirus DNA replication and cell cycle interactions. Vet Microbiol 98(2): 111-119.

114. Horvath GV, Pettko-Szandtner A, Nikovics K, Bilgin M, Boulton M, Davies JW, Gutierrez C, Dudits D (1998). Prediction of functional regions of the maize streak virus replication-associated proteins by protein-protein interaction analysis. Plant Mol Biol 38(5): 699-712.

115. Shepherd DN, Martin DP, McGivern DR, Boulton MI, Thomson JA, Rybicki EP (2005). A three-nucleotide mutation altering the Maize streak virus Rep pRBR-interaction motif reduces symptom severity in maize and partially reverts at high frequency without restoring pRBRRep binding. J Gen Virol 86(Pt 3): 803-813.

116. Hipp K, Rau P, Schafer B, Gronenborn B, Jeske H (2014). The RXL motif of the African cassava mosaic virus Rep protein is necessary for rereplication of yeast DNA and viral infection in plants. Virology 462463:189-198.

117. Yamamura Y, Scholthof HB (2005). Tomato bushy stunt virus: a resilient model system to study virus-plant interactions. Mol Plant Pathol 6(5): 491-502.

118. Lau E, Zhu C, Abraham RT, Jiang W (2006). The functional role of Cdc6 in S-G2/M in mammalian cells. EMBO Rep 7(4): 425-430.

119. Nawaz-ul-Rehman MS, Reddisiva Prasanth K, Baker J, Nagy PD (2013). Yeast screens for host factors in positive-strand RNA virus replication based on a library of temperature-sensitive mutants. Methods 59(2): 207-216.

120. Nascimento R, Costa H, Parkhouse RM (2012). Virus manipulation of cell cycle. Protoplasma 249(3): 519-528.

121. Swanton C, Jones N (2001). Strategies in subversion: deregulation of the mammalian cell cycle by viral gene products. Int J Exp Pathol 82(1): 3-13.

122. Bagga S, Bouchard MJ (2014). Cell cycle regulation during viral infection. Methods Mol Biol 1170(165-227.

123. Davy C, Doorbar J (2007). G2/M cell cycle arrest in the life cycle of viruses. Virology 368(2): 219-226.

124. Dove B, Brooks G, Bicknell K, Wurm T, Hiscox JA (2006). Cell cycle perturbations induced by infection with the coronavirus infectious bronchitis virus and their effect on virus replication. J Virol 80(8): 4147-4156.

125. He Y, Xu K, Keiner B, Zhou J, Czudai V, Li T, Chen Z, Liu J, Klenk $H D$, Shu YL, Sun B (2010). Influenza A virus replication induces cell cycle arrest in G0/G1 phase. J Virol 84(24): 12832-12840.

126. D'Urso M, Zucchi I, Ciccodicola A, Palmieri G, Abidi FE, Schlessinger D (1990). Human glucose-6-phosphate dehydrogenase gene carried on a yeast artificial chromosome encodes active enzyme in monkey cells. Genomics 7(4): 531-534.

127. Macreadie IG, Castelli LA, Hewish DR, Kirkpatrick A, Ward AC, Azad AA (1995). A domain of human immunodeficiency virus type 1 Vpr containing repeated H(S/F)RIG amino acid motifs causes cell growth arrest and structural defects. Proc Natl Acad Sci U S A 92(7): 2770-2774.

128. Zhao Y, Cao J, O'Gorman MR, Yu M, Yogev R (1996). Effect of human immunodeficiency virus type 1 protein $R$ (vpr) gene expression on basic cellular function of fission yeast Schizosaccharomyces pombe. J Virol 70(9): 5821-5826.
129. Jin DY, Spencer F, Jeang KT (1998). Human T cell leukemia virus type 1 oncoprotein Tax targets the human mitotic checkpoint protein MAD1. Cell 93(1): 81-91.

130. Fournier N, Raj K, Saudan P, Utzig S, Sahli R, Simanis V, Beard P (1999). Expression of human papillomavirus 16 E2 protein in Schizosaccharomyces pombe delays the initiation of mitosis. Oncogene 18(27): 4015-4021.

131. Yao XJ, Rougeau N, Duisit G, Lemay J, Cohen EA (2004). Analysis of HIV-1 Vpr determinants responsible for cell growth arrest in Saccharomyces cerevisiae. Retrovirology 1:21.

132. Nakazawa J, Watanabe N, Imoto M, Osada H (2005). Mutational analysis of growth arrest and cellular localization of human immunodeficiency virus type $1 \mathrm{Vpr}$ in the budding yeast, Saccharomyces cerevisiae. J Gen Appl Microbiol 51(4): 245-256.

133. Hattori N, Michaels F, Fargnoli K, Marcon L, Gallo RC, Franchini G (1990). The human immunodeficiency virus type $2 \mathrm{vpr}$ gene is essential for productive infection of human macrophages. Proc Natl Acad Sci U S A 87(20): 8080-8084.

134. He J, Choe S, Walker R, Di Marzio P, D., Morgan DO, Landau NR (1995). Human immunodeficiency virus type 1 viral protein $R(V p r)$ arrests cells in the $\mathrm{G} 2$ phase of the cell cycle by inhibiting p34cdc2 activity. J Virol 69(11): 6705-6711.

135. Heinzinger N, Bukinsky M, Haggerty S, Ragland A, Kewalramani V, Lee M, Gendelman H, Ratner L, Stevenson M, Emerman M (1994). The Vpr protein of human immunodeficiency virus type 1 influences nuclear localization of viral nucleic acids in nondividing host cells. Proc Natl Acad Sci USA 91(15): 7311-7315.

136. Zhao RY, Li G, Bukrinsky MI (2011). Vpr-host interactions during HIV-1 viral life cycle. J Neuroimmune Pharmacol 6(2): 216-229.

137. Re F, Braaten D, Franke EK, Luban J (1995). Human immunodeficiency virus type $1 \mathrm{Vpr}$ arrests the cell cycle in $\mathrm{G} 2$ by inhibiting the activation of p34 ${ }^{\text {cdc2 }}$-cyclin B. J Virol 69(11): 6859-6864.

138. Majumder B, Venkatachari NJ, Srinivasan A, Ayyavoo V (2009). HIV-1 mediated immune pathogenesis: spotlight on the role of viral protein R (Vpr). Curr HIV Res 7(2): 169-177.

139. Levy DN, Refaeli Y, MacGregor RR, Weiner DB (1994). Serum Vpr regulates productive infection and latency of human immunodeficiency virus type 1. Proc Natl Acad Sci U S A 91(23): 10873-10877.

140. Rhind N, Russell P (1998). Mitotic DNA damage and replication checkpoints in yeast. Curr Opin Cell Biol 10(6): 749-758.

141. Yasutis KM, Kozminski KG (2013). Cell cycle checkpoint regulators reach a zillion. Cell Cycle 12(10): 1501-1509.

142. Jowett JB, Planelles V, Poon B, Shah NP, Chen ML, Chen IS (1995). The human immunodeficiency virus type $1 \mathrm{vpr}$ gene arrests infected $\mathrm{T}$ cells in the G2 + M phase of the cell cycle. J Virol 69(10): 6304-6313.

143. Goh WC, Manel N, Emerman M (2004). The human immunodeficiency virus $\mathrm{Vpr}$ protein binds Cdc25C: implications for G2 arrest. Virology 318(1): 337-349.

144. Kamata $M$, Watanabe $N$, Nagaoka $Y$, Chen IS (2008). Human immunodeficiency virus type $1 \mathrm{Vpr}$ binds to the $\mathrm{N}$ lobe of the Wee1 kinase domain and enhances kinase activity for CDC2. J Virol 82(12): 5672-5682.

145. Elder RT, Yu M, Chen M, Zhu X, Yanagida M, Zhao Y (2001). HIV-1 $\mathrm{Vpr}$ induces cell cycle $\mathrm{G} 2$ arrest in fission yeast (Schizosaccharomyces pombe) through a pathway involving regulatory and catalytic subunits of PP2A and acting on both Wee1 and Cdc25. Virology 287(2): 359370.

146. DeHart JL, Zimmerman ES, Ardon O, Monteiro-Filho CM, Arganaraz ER, Planelles $V$ (2007). HIV-1 Vpr activates the G2 checkpoint 
through manipulation of the ubiquitin proteasome system. Virol J $4: 57$.

147. Tan L, Ehrlich E, Yu XF (2007). DDB1 and Cul4A are required for human immunodeficiency virus type $1 \mathrm{Vpr}$-induced G2 arrest. J Virol 81(19): 10822-10830.

148. Li G, Elder RT, Dubrovsky L, Liang D, Pushkarsky T, Chiu K, Fan T, Sire J, Bukrinsky M, Zhao RY (2010). HIV-1 replication through hHR23A-mediated interaction of Vpr with $26 \mathrm{~S}$ proteasome. PLoS One 5(6): e11371.

149. Gragerov A, Kino T, Ilyina-Gragerova G, Chrousos GP, Pavlakis GN (1998). HHR23A, the human homologue of the yeast repair protein RAD23, interacts specifically with $\mathrm{Vpr}$ protein and prevents cell cycle arrest but not the transcriptional effects of Vpr. Virology 245(2): 323330.

150. Elder RT, Song XQ, Chen M, Hopkins KM, Lieberman HB, Zhao $Y$ (2002). Involvement of rhp23, a Schizosaccharomyces pombe homolog of the human HHR23A and Saccharomyces cerevisiae RAD23 nucleotide excision repair genes, in cell cycle control and protein ubiquitination. Nucleic Acids Res 30(2): 581-591.

151. Bartz SR, Rogel ME, Emerman M (1996). Human immunodeficiency virus type 1 cell cycle control: $\mathrm{Vpr}$ is cytostatic and mediates $\mathrm{G} 2$ accumulation by a mechanism which differs from DNA damage checkpoint control. J Virol 70(4): 2324-2331.

152. Roshal M, Kim B, Zhu Y, Nghiem P, Planelles V (2003). Activation of the ATR-mediated DNA damage response by the HIV-1 viral protein R. J Biol Chem 278(28): 25879-25886.

153. Masuda $M$, Nagai $Y$, Oshima N, Tanaka K, Murakami $H$, Igarashi $H$, Okayama H (2000). Genetic studies with the fission yeast Schizosaccharomyces pombe suggest involvement of wee1, ppa2, and rad24 in induction of cell cycle arrest by human immunodeficiency virus type 1 Vpr. J Virol 74(6): 2636-2646.

154. Li G, Elder RT, Qin K, Park HU, Liang D, Zhao RY (2007). Phosphatase type 2A-dependent and -independent pathways for ATR phosphorylation of Chk1. J Biol Chem 282(10): 7287-7298.

155. Matsuda N, Tanaka H, Yamazaki S, Suzuki J, Tanaka K, Yamada T, Masuda M (2006). HIV-1 Vpr induces G2 cell cycle arrest in fission yeast associated with Rad24/14-3-3-dependent, Chk1/Cds1independent Wee1 upregulation. Microbes Infect 8(12-13): 27362744.

156. Li G, Park HU, Liang D, Zhao RY (2010). Cell cycle G2/M arrest through an $S$ phase-dependent mechanism by HIV-1 viral protein R. Retrovirology 7:59.

157. Schwartz LM, Osborne BA (1993). Programmed cell death, apoptosis and killer genes. Immunol Today 14(12): 582-590.

158. Madeo F, Herker E, Wissing S, Jungwirth $H$, Eisenberg T, Frohlich KU (2004). Apoptosis in yeast. Curr Opin Microbiol 7(6): 655-660.

159. Buttner S, Eisenberg T, Herker E, Carmona-Gutierrez D, Kroemer $G$, Madeo $F$ (2006). Why yeast cells can undergo apoptosis: death in times of peace, love, and war. J Cell Biol 175(4): 521-525.

160. Frohlich KU, Fussi H, Ruckenstuhl C (2007). Yeast apoptosis-from genes to pathways. Semin Cancer Biol 17(2): 112-121.

161. Falcone C, Mazzoni C (2016). External and internal triggers of cell death in yeast. Cell Mol Life Sci 73(11-12): 2237-2250.

162. Madeo F, Frohlich E, Frohlich KU (1997). A yeast mutant showing diagnostic markers of early and late apoptosis. J Cell Biol 139(3): 729734

163. Manon S, Guerin M (1997). The ATP-induced K(+)-transport pathway of yeast mitochondria may function as an uncoupling pathway. Biochim Biophys Acta 1318(3): 317-321.
164. Madeo F, Herker E, Maldener C, Wissing S, Lachelt S, Herlan M, Fehr M, Lauber K, Sigrist SJ, Wesselborg S, Frohlich KU (2002). A caspase-related protease regulates apoptosis in yeast. Mol Cell 9(4): 911-917.

165. Burhans WC, Weinberger $M$, Marchetti MA, Ramachandran L, D'Urso G, Huberman JA (2003). Apoptosis-like yeast cell death in response to DNA damage and replication defects. Mutat Res 532(1-2): 227-243.

166. Mazzoni C, Falcone C (2008). Caspase-dependent apoptosis in yeast. Biochim Biophys Acta 1783(7): 1320-1327.

167. Carmona-Gutierrez D, Eisenberg T, Buttner S, Meisinger C, Kroemer $G$, Madeo $F$ (2010). Apoptosis in yeast: triggers, pathways, subroutines. Cell Death Differ 17(5): 763-773.

168. Azzopardi M, Farrugia G, Balzan R (2017). Cell-cycle involvement in autophagy and apoptosis in yeast. Mech Ageing Dev 161(Pt B): 211224.

169. Rodriguez-Menocal L, D'Urso G (2004). Programmed cell death in fission yeast. FEMS Yeast Res 5(2): 111-117.

170. Ink B, Zornig M, Baum B, Hajibagheri N, James C, Chittenden T, Evan G (1997). Human Bak induces cell death in Schizosaccharomyces pombe with morphological changes similar to those with apoptosis in mammalian cells. Mol Cell Biol 17(5): 2468-2474.

171. Jurgensmeier JM, Krajewski S, Armstrong RC, Wilson GM, Oltersdorf T, Fritz LC, Reed JC, Ottilie S (1997). Bax- and Bak-induced cell death in the fission yeast Schizosaccharomyces pombe. Mol Biol Cell 8(2): 325-339.

172. Low CP, Yang $H$ (2008). Programmed cell death in fission yeast Schizosaccharomyces pombe. Biochim Biophys Acta 1783(7): 13351349.

173. Liang Q, Li W, Zhou B (2008). Caspase-independent apoptosis in yeast. Biochim Biophys Acta 1783(7): 1311-1319.

174. Clem RJ (2001). Baculoviruses and apoptosis: the good, the bad, and the ugly. Cell Death Differ 8(2): 137-143.

175. Kleinberger T (2004). Induction of transformed cell-specific apoptosis by the adenovirus E4orf4 protein. Prog Mol Subcell Biol 36:245267.

176. Jacotot E, Ravagnan L, Loeffler M, Ferri KF, Vieira HL, Zamzami N, Costantini $P$, Druillennec $S$, Hoebeke J, Briand JP, Irinopoulou T, Daugas E, Susin SA, Cointe D, Xie ZH, Reed JC, Roques BP, Kroemer G (2000). The HIV-1 viral protein $R$ induces apoptosis via a direct effect on the mitochondrial permeability transition pore. J Exp Med 191(1): 33-46.

177. Blanco R, Carrasco L, Ventoso I (2003). Cell killing by HIV-1 protease. J Biol Chem 278(2): 1086-1093.

178. Rumlova M, Krizova I, Keprova A, Hadravova R, Dolezal M, Strohalmova K, Pichova I, Hajek M, Ruml T (2014). HIV-1 protease-induced apoptosis. Retrovirology 11:37.

179. Benko Z, Elder RT, Li G, Liang D, Zhao RY (2016). HIV-1 Protease in the Fission Yeast Schizosaccharomyces pombe. PLoS One 11(3): e0151286.

180. Benko Z, Liang D, Li G, Elder RT, Sarkar A, Takayama J, Ghosh AK, Zhao RY (2017). A fission yeast cell-based system for multidrug resistant HIV-1 proteases. Cell Biosci 7:5.

181. Banadyga L, Lam SC, Okamoto T, Kvansakul M, Huang DC, Barry $M$ (2011). Deerpox virus encodes an inhibitor of apoptosis that regulates Bak and Bax. J Virol 85(5): 1922-1934.

182. Korant BD, Strack P, Frey MW, Rizzo CJ (1998). A cellular antiapoptosis protein is cleaved by the HIV-1 protease. Adv Exp Med Biol 436:27-29. 
183. Ventoso I, Navarro J, Munoz MA, Carrasco L (2005). Involvement of HIV-1 protease in virus-induced cell killing. Antiviral Res 66(1): 4755.

184. Nie Z, Bren GD, Vlahakis SR, Schimnich AA, Brenchley JM, Trushin SA, Warren S, Schnepple DJ, Kovacs CM, Loutfy MR, Douek DC, Badley $A D$ (2007). Human immunodeficiency virus type 1 protease cleaves procaspase 8 in vivo. J Virol 81(13): 6947-6956.

185. Sloand EM, Maciejewski J, Kumar P, Kim S, Chaudhuri A, Young N (2000). Protease inhibitors stimulate hematopoiesis and decrease apoptosis and ICE expression in CD34(+) cells. Blood 96(8): 2735-2739.

186. Phenix BN, Angel JB, Mandy F, Kravcik S, Parato K, Chambers KA Gallicano K, Hawley-Foss N, Cassol S, Cameron DW, Badley AD (2000). Decreased HIV-associated T cell apoptosis by HIV protease inhibitors. AIDS Res Hum Retroviruses 16(6): 559-567.

187. Nie Z, Phenix BN, Lum JJ, Alam A, Lynch DH, Beckett B, Krammer PH, Sekaly RP, Badley AD (2002). HIV-1 protease processes procaspase 8 to cause mitochondrial release of cytochrome c, caspase cleavage and nuclear fragmentation. Cell Death Differ 9(11): 11721184.

188. Ravaux I, Perrin-East C, Attias C, Cottalorda J, Durant J, Dellamonica P, Gluschankof P, Stein A, Tamalet C (2014). Yeast cells as a tool for analysis of HIV-1 protease susceptibility to protease inhibitors, a comparative study. J Virol Methods 195:180-184.

189. Perez MA, Fernandes PA, Ramos MJ (2010). Substrate recognition in HIV-1 protease: a computational study. J Phys Chem B 114(7): 2525-2532.

190. Dunn BM, Goodenow MM, Gustchina A, Wlodawer A (2002). Retroviral proteases. Genome Biol 3(4): REVIEWS3006

191. Yaffe MP, Harata D, Verde F, Eddison M, Toda T, Nurse P (1996). Microtubules mediate mitochondrial distribution in fission yeast. Proc Natl Acad Sci U S A 93(21): 11664-11668.

192. Macreadie IG, Arunagiri CK, Hewish DR, White JF, Azad AA (1996). Extracellular addition of a domain of HIV-1 Vpr containing the amino acid sequence motif $\mathrm{H}(\mathrm{S} / \mathrm{F}) \mathrm{RIG}$ causes cell membrane permeabilization and death. Mol Microbiol 19(6): 1185-1192.

193. Rajan D, Wildum S, Rucker E, Schindler M, Kirchhoff $F$ (2006). Effect of R77Q, R77A and R80A changes in Vpr on HIV-1 replication and CD4 T cell depletion in human lymphoid tissue ex vivo. AIDS (London, England) 20(6): 831-836.

194. Macreadie IG, Thorburn DR, Kirby DM, Castelli LA, de Rozario NL, Azad AA (1997). HIV-1 protein Vpr causes gross mitochondrial dysfunction in the yeast Saccharomyces cerevisiae. FEBS Lett 410(2-3): 145-149.

195. Arunagiri C, Macreadie I, Hewish D, Azad A (1997). A C-terminal domain of HIV-1 accessory protein $\mathrm{Vpr}$ is involved in penetration, mitochondrial dysfunction and apoptosis of human CD4+ lymphocytes. Apoptosis 2(1): 69-76.

196. Maundrell K (1990). nmt1 of fission yeast. A highly transcribed gene completely repressed by thiamine. J Biol Chem 265(19): 1085710864.

197. Dayton Al, Terwilliger EF, Potz J, Kowalski M, Sodroski JG, Haseltine WA (1988). Cis-acting sequences responsive to the rev gene product of the human immunodeficiency virus. J Acquir Immune Defic Syndr 1(5): 441-452.

198. Pollard VW, Malim MH (1998). The HIV-1 Rev protein. Annu Rev Microbiol 52:491-532.

199. Fineberg K, Fineberg T, Graessmann A, Luedtke NW, Tor Y, Lixin $R$, Jans DA, Loyter A (2003). Inhibition of nuclear import mediated by the Rev-arginine rich motif by RNA molecules. Biochemistry 42(9): 2625-2633.
200. Levin A, Hayouka Z, Friedler A, Loyter A (2010). Nucleocytoplasmic shuttling of HIV-1 integrase is controlled by the viral Rev protein. Nucleus 1(2): 190-201.

201. Kim JM, Vanguri S, Boeke JD, Gabriel A, Voytas DF (1998). Transposable elements and genome organization: a comprehensive survey of retrotransposons revealed by the complete Saccharomyces cerevisiae genome sequence. Genome Res 8(5): 464-478.

202. Stutz F, Neville M, Rosbash M (1995). Identification of a novel nuclear pore-associated protein as a functional target of the HIV-1 Rev protein in yeast. Cell 82(3): 495-506.

203. Hockenbery DM, Oltvai ZN, Yin XM, Milliman CL, Korsmeyer SJ (1993). Bcl-2 functions in an antioxidant pathway to prevent apoptosis. Cell 75(2): 241-251.

204. Kane GM (1993). What is a good death? Bioethics Forum 9(1): 26-30.

205. Qian X, Nguyen HN, Song MM, Hadiono C, Ogden SC, Hammack C, Yao B, Hamersky GR, Jacob F, Zhong C, Yoon KJ, Jeang W, Lin L, Li Y, Thakor J, Berg DA, Zhang C, Kang E, Chickering M, Nauen D, Ho CY, Wen Z, Christian KM, Shi PY, Maher BJ, Wu H, Jin P, Tang $H$, Song $H$, Ming GL (2016). Brain-Region-Specific Organoids Using Minibioreactors for Modeling ZIKV Exposure. Cell 165(5): 1238-1254.

206. Cugola FR, Fernandes IR, Russo FB, Freitas BC, Dias JL, Guimaraes $\mathrm{KP}$, Benazzato C, Almeida N, Pignatari GC, Romero S, Polonio CM, Cunha I, Freitas CL, Brandao WN, Rossato C, Andrade DG, Faria Dde $P$, Garcez AT, Buchpigel CA, Braconi CT, Mendes E, Sall AA, Zanotto PM, Peron JP, Muotri AR, Beltrao-Braga PC (2016). The Brazilian Zika virus strain causes birth defects in experimental models. Nature 534(7606): 267-271.

207. Dang J, Tiwari SK, Lichinchi G, Qin Y, Patil VS, Eroshkin AM, Rana TM (2016). Zika Virus Depletes Neural Progenitors in Human Cerebral Organoids through Activation of the Innate Immune Receptor TLR3. Cell Stem Cell 19(2):258-65

208. Li C, Xu D, Ye Q, Hong S, Jiang Y, Liu X, Zhang N, Shi L, Qin CF, Xu Z (2016). Zika Virus Disrupts Neural Progenitor Development and Leads to Microcephaly in Mice. Cell Stem Cell 19(1): 120-126.

209. Tang H, Hammack C, Ogden SC, Wen Z, Qian X, Li Y, Yao B, Shin J, Zhang $F$, Lee EM, Christian KM, Didier RA, Jin $P$, Song $H$, Ming GL (2016). Zika Virus Infects Human Cortical Neural Progenitors and Attenuates Their Growth. Cell Stem Cell 18(5):587-90.

210. Nguyen HN, Qian X, Song H, Ming GL (2016). Neural stem cells attacked by Zika virus. Cell Res 26(7): 753-754.

211. Garcez PP, Loiola EC, Madeiro da Costa R, Higa LM, Trindade $P$, Delvecchio R, Nascimento JM, Brindeiro R, Tanuri A, Rehen SK (2016) Zika virus impairs growth in human neurospheres and brain organoids. Science 352(6287): 816-818.

212. Nasmyth K (2001). A prize for proliferation. Cell 107(6): 689-701.

213. Faye O, Freire CC, lamarino A, Faye O, de Oliveira JV, Diallo M, Zanotto PM, Sall AA (2014). Molecular evolution of Zika virus during its emergence in the 20(th) century. PLoS Negl Trop Dis 8(1): e2636.

214. Harris E, Holden KL, Edgil D, Polacek C, Clyde K (2006). Molecular biology of flaviviruses. Novartis Found Symp 277:23-39; discussion 40 71-23, 251-253

215. Bell TM, Field EJ, Narang HK (1971). Zika virus infection of the central nervous system of mice. Arch Gesamte Virusforsch 35(2): 183 193.

216. Moran M, Delmiro A, Blazquez A, Ugalde C, Arenas J, Martin MA (2014). Bulk autophagy, but not mitophagy, is increased in cellular model of mitochondrial disease. Biochim Biophys Acta 1842(7): 10591070 . 
217. Romero-Brey I, Bartenschlager R (2016). Endoplasmic Reticulum: The Favorite Intracellular Niche for Viral Replication and Assembly. Viruses 8(6).

218. Kaufusi PH, Kelley JF, Yanagihara R, Nerurkar VR (2014). Induction of endoplasmic reticulum-derived replication-competent membrane structures by West Nile virus non-structural protein 4B. PLoS One 9(1): e84040.

219. Liang Q, Luo Z, Zeng J, Chen W, Foo SS, Lee SA, Ge J, Wang S, Goldman SA, Zlokovic BV, Zhao Z, Jung JU (2016). Zika Virus NS4A and NS4B Proteins Deregulate Akt-mTOR Signaling in Human Fetal Neural Stem Cells to Inhibit Neurogenesis and Induce Autophagy. Cell Stem Cell 19(5):663-671.

220. Sun LL, Li M, Suo F, Liu XM, Shen EZ, Yang B, Dong MQ, He WZ, Du LL (2013). Global analysis of fission yeast mating genes reveals new autophagy factors. PLoS Genet 9(8): e1003715.

221. Weisman R, Roitburg I, Schonbrun M, Harari R, Kupiec M (2007). Opposite effects of tor1 and tor2 on nitrogen starvation responses in fission yeast. Genetics 175(3): 1153-1162.

222. Fenyvuesvolgyi C, Elder RT, Benko Z, Liang D, Zhao RY (2005). Fission yeast homologue of Tip41-like proteins regulates type $2 \mathrm{~A}$ phosphatases and responses to nitrogen sources. Biochim Biophys Acta 1746(2): 155-162.

223. Bukrinsky M (2017). Yeast help identify cytopathic factors of Zika virus. Cell Biosci 7:12.

224. Trepo C (2014). A brief history of hepatitis milestones. Liver Int 34 Suppl 1:29-37.

225. Gunthard HF, Saag MS, Benson CA, del Rio C, Eron JJ, Gallant JE, Hoy JF, Mugavero MJ, Sax PE, Thompson MA, Gandhi RT, Landovitz RJ, Smith DM, Jacobsen DM, Volberding PA (2016). Antiretroviral Drugs for Treatment and Prevention of HIV Infection in Adults: 2016 Recommendations of the International Antiviral Society-USA Panel. Jama 316(2): 191-210.

226. Smith SM (2005). New York City HIV superbug: fear or fear not? Retrovirology 2:14.

227. Brower $V$ (2005). New superbug or tempest in a teapot? EMBO $\operatorname{Rep} 6(6)$ : 502-504.

228. Agniswamy J, Shen CH, Wang YF, Ghosh AK, Rao KV, Xu CX, Sayer JM, Louis JM, Weber IT (2013). Extreme multidrug resistant HIV-1 protease with 20 mutations is resistant to novel protease inhibitors with P1'-pyrrolidinone or P2-tris-tetrahydrofuran. J Med Chem 56(10): 4017-4027.

229. Schuhmacher A, Gassmann O, Hinder M (2016). Changing R\&D models in research-based pharmaceutical companies. J Transl Med 14(1): 105.

230. Hughes JP, Rees S, Kalindjian SB, Philpott KL (2011). Principles of early drug discovery. Br J Pharmacol 162(6): 1239-1249.

231. Yang H, Nkeze J, Zhao RY (2012). Effects of HIV-1 protease on cellular functions and their potential applications in antiretroviral therapy. Cell Biosci 2(1): 32.
232. Benko Z, Elder RT, Liang D, Zhao RY (2010). Fission yeast as a HTS platform for molecular probes of HIV-1 Vpr-induced cell death. Int J High Throughput Screen 2010(1): 151 - 162.

233. Cottier V, Barberis A, Luthi U (2006). Novel yeast cell-based assay to screen for inhibitors of human cytomegalovirus protease in a highthroughput format. Antimicrob Agents Chemother 50(2): 565-571.

234. Voisset C, Daskalogianni C, Contesse MA, Mazars A, Arbach H, Le Cann M, Soubigou F, Apcher S, Fahraeus R, Blondel M (2014). A yeastbased assay identifies drugs that interfere with immune evasion of the Epstein-Barr virus. Dis Model Mech 7(4): 435-444.

235. Liu H, Wu R, Sun Y, Ye Y, Chen J, Luo X, Shen X, Liu H (2014). Identification of novel thiadiazoloacrylamide analogues as inhibitors of dengue-2 virus NS2B/NS3 protease. Bioorg Med Chem 22(22): 63446352.

236. Balgi AD, Wang J, Cheng DY, Ma C, Pfeifer TA, Shimizu Y, Anderson HJ, Pinto LH, Lamb RA, DeGrado WF, Roberge M (2013). Inhibitors of the influenza A virus $M 2$ proton channel discovered using a highthroughput yeast growth restoration assay. PLoS One 8(2): e55271.

237. Beljaars L, van der Strate BW, Bakker HI, Reker-Smit C, van Loenen-Weemaes AM, Wiegmans FC, Harmsen MC, Molema G, Meijer DK (2004). Inhibition of cytomegalovirus infection by lactoferrin in vitro and in vivo. Antiviral Res 63(3): 197-208.

238. Ison MG (2017). Antiviral Treatments. Clin Chest Med 38(1): 139153.

239. Goh WC, Rogel ME, Kinsey CM, Michael SF, Fultz PN, Nowak MA, Hahn BH, Emerman M (1998). HIV-1 Vpr increases viral expression by manipulation of the cell cycle: a mechanism for selection of $\mathrm{Vpr}$ in vivo. Nat Med 4(1): 65-71.

240. Gibbs JS, Lackner AA, Lang SM, Simon MA, Sehgal PK, Daniel MD, Desrosiers RC (1995). Progression to AIDS in the absence of a gene for vpr or vpx. J Virol 69:2378-2383.

241. Lang SM, Weeger M, Stahl-Hennig C, Coulibaly C, Hunsmann G, Muller J, Muller-Hermelink H, Fuchs D, Wachter $H$, Daniel MM, Desrosiers RC, Fleckenstein B (1993). Importance of vpr for infection of rhesus monkeys with simian immunodeficiency virus. J Virol 67(2): 902-912.

242. Zhao $Y$, Chen M, Wang B, Yang J, Elder RT, Song XQ, Yu M, Saksena NK (2002). Functional conservation of HIV-1 Vpr and variability in a mother-child pair of long-term non-progressors. Virus Res 89(1): 103-121.

243. Somasundaran $M$, Sharkey $M$, Brichacek B, Luzuriaga $K$, Emerman M, Sullivan JL, Stevenson M (2002). Evidence for a cytopathogenicity determinant in HIV-1 Vpr. Proc Natl Acad Sci U S A 99(14): 9503-9508.

244. Zhao RY, Elder RT, Bukrinsky M (2007). Interactions of HIV-1 viral protein R with host cell proteins. Adv Pharmacol 55:233-260.

245. Coffin JM (1996). Response: Plasma Viral Load, CD4+ Cell Counts, and HIV-1 Production by Cells. Science 271(5249): 671. 